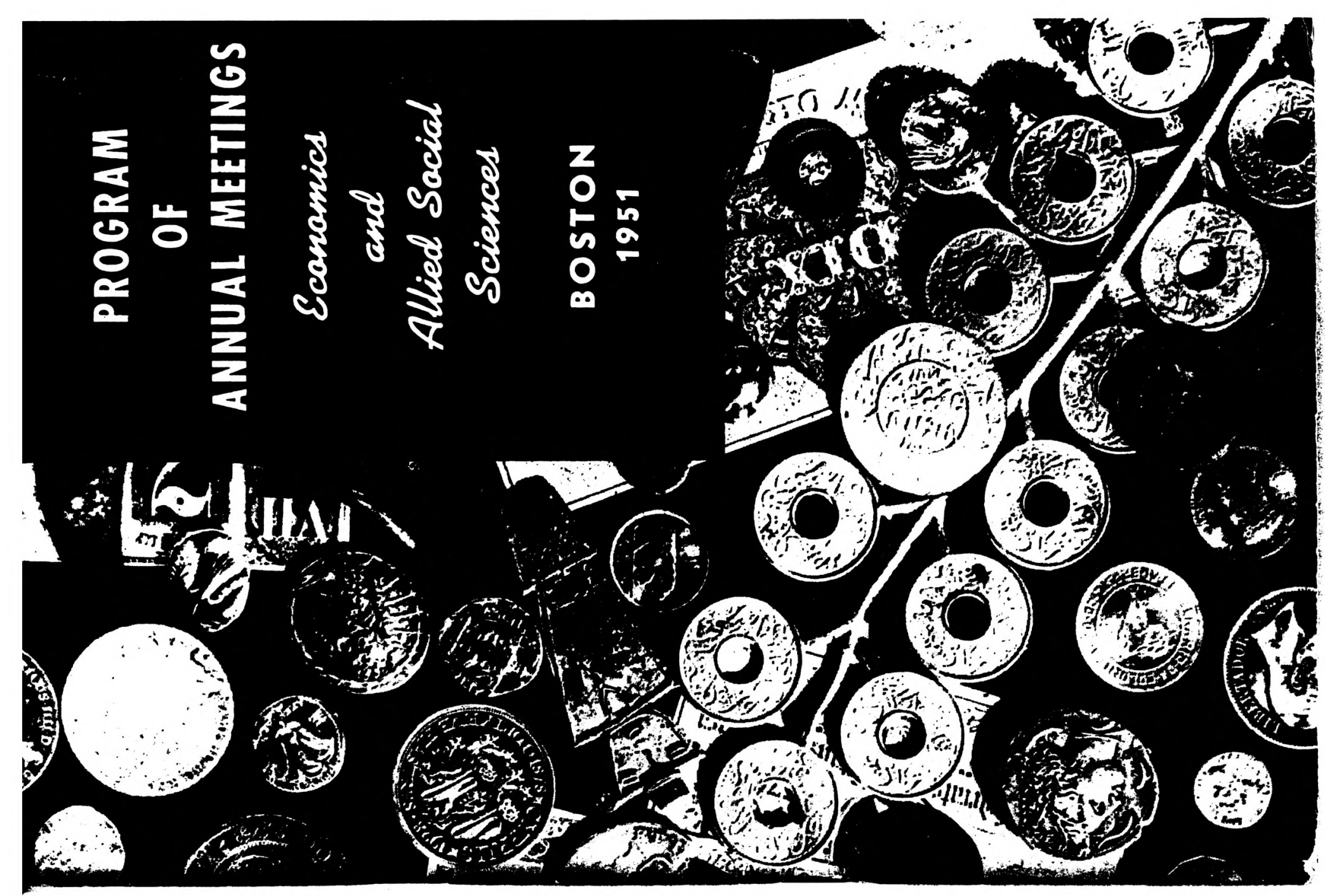




\section{GONVENING ASSOGIATIONS}

AMERICAN ECONOMIC ASSOCIATION AMERICAN STATISTICAL ASSOCIATION AMERICAN MARKETING ASSOCIATION AMERICAN FINANCE ASSOCIATION ECONOMETRIC SOCIETY

CATHOLIC ECONOMIC ASSOCIATION

INSTITUTE OF MATHEMATICAL STATISTICS

AMERICAN ASSOCIATION OF UNIVERSITY TEACHERS

OF INSURANCE

INDUSTRIAL RELATIONS RESEARCH ASSÓCIATION

Holding Joint Meetings With

American Farm Economics Association

Population Association of America

Biometrics Society

Boston Security Analysts Society

American Society for Quality Control

Rural Sociological Society

Social Worle Research Group

American Sociological Society

Society of Actuaries

- Economic History Association

American Public Health Association

\section{GENERAL INFORMATION}

This is a joint program containing the schedule of meetings for the Allied Social Science Associations meeting in Boston from Wednesday, December 26 , through Saturday, December 29. are listed separately on pages 2-3.

Associations participating in joint sessions are designated by abbreviation, and the key to these abbreviations is on page 3 .

\section{Registration}

The fee charged for registration by all participating associations is $\$ 2.00$, except for the American Marketing Association. Registration entitles members to attend sessions sponsored by all participating associations. Full-time students are invited to attend meetings free of charge but are requested to register using student registration forms.

Registration for the various associations will commence on Wednesday, December 26, at the following hotels.

Statler: American Economic Association American Finance Association

Catholic Economic Associr

Copley-Plaza: American Statistical Association Institute of Mathematical Statistics Econometric Society

Kenmore: American Marketing Association

Somerset: Industrial Relations Research Association

Information concerning registrants, meetings, and other matters may be obtained at the information tables or at the various registration desks. The Room of the Statler.

\section{The Employment Register}

An employment register has been set up on the mezzanine of the Statler. This is for the use of persons seeking personnel or employment in economics, statistics, or related fields. Application blanks and vacancy forms will be available at this desk. Lists of vacancies and of applicants will be made available to prospective employees and employers. Parlor $\mathrm{F}$ at the Statler is available as an employment conference room during most of the Convention hours.

\section{Book Exhibits and Advertisements}

At the Statler, book publishers' exhibits are located in the Foyer of the Ballroom on the Mezzanine. At the Kenmore, exhibits of publishers and related firms are in the lower Lobby and Wedgewood Room.

Lists of exhibitors and of advertisers in the program appear in the last section of the program.

\section{Press Room}

A press headquarters has been established in Parlor E at the Statler. Summaries of papers and the manuscripts should be taken directly to that room. Al such summaries and manuscripts should be properly identified as to time and title of session, name of author, etc. At the Kenmore, Somerset, and CopleyPlaza hotels, papers may be left at the information desks for rapid transmission by messenger to press headquarters. 


\section{SPECIAL EVENTS}

Listed below are a number of meetings which are of interest to particular groups but are not included in the body of the program. The list is not necessarily complete. It contains all such events made known to the Local Arrangements Committee. Consult the information desks or committee headquarters for further details.

The American Association of Collegiate Schools of Business will hold meeting Dec. 27 through Dec. 29 on the 4th floor of the Statler.

\section{WEDNESDAY, DEGEMBER 26}

American Economic Association, Executive Committee Meeting, Statler, Parlor D, 2:30 P.M.

\section{THURSDAY, DECEMBER 27}

Princeton Dinner, University Club (40 Trinity Place), 6:15 P.M.

Americar Finance Association, Executive Dinner, Statler, Parlor F, 6:30 P.M.

\section{FRIDAY, DECEMBER 28}

All Associations: Breakfast meeting, Statler, Parlor C, 8:00 A.M. Topic: COLLEGE REGreenough TQ TITIES FUND PROPOSALS. Speaker: William \$2.00, at Information Desk by 6:00 P.M., Thursday, December 27.)

Metropolitan Economic Association, New York, Statler, Parlor F, 4:00 P.M.

International Institute of Public Finance, Statler, Parlor D, 4:00 P.M.

All Associations:

Boston Pops Concert - 8:30 P.M. - Statler Ballroom. Tickets should be obtained from the registration desk by Thursday noon. Price $\$ 1.00$.

\section{SATURDAY, DECEMBER 29}

Biometrics Society, Annual Business Meeting, Copley-Plaza, Room 131, 8:30-9:20 A.M.

American Economic Association, Executive Committee Meeting, Statler, Parlor D, 10 A.M.

\section{TOURS}

\section{Harvard Computation Laboratory}

Description: A conducted visit to the Computation Laboratory, including a description of the electronic computor.

Time: At 9:30 and 10:30 A.M. Friday, December 28. in advance, because each tour is limited to 20 persons.

\section{Federal Reserve Bank of Boston}

Description: Conducted tour of money, check clearance, money order,

Time: and other section of the bank.

Time: At 10:00 A.M. and 2:00 P.M. on Thursday, Dec. 27, and

Place: Meet at Reception Desk, Main Floor, 30 Pearl Street.

John Hancock Mutual Life Insurance Company

Description: Conducted tour of the home office building, including the

Observation Tower.

Time: At 2:00 P.M. Thursday, Dec. 27, and 10:00 A.M. Friday,

Place: Lobby, 200 Berkeley Street
Liberty Mutual Insurance Companies

Description: A tour of the Rehabilitation Center for handicapped

Time: At 10:00 A.M. and 2:00 P.M. on Thursday, Dec. 27, and Friday, Dec. 28.

Place: Meet at Information Desk, Copley-Plaza Hotel.

Description: A tour of the Tabulating Installation.

Time: At 3:30 P.M. Thursday, Dec. 27, and Friday, Dec. 28.

Place: Meet at Information Desk, Copley-Plaza Hotel. Description: A tour of the Research Department where Dr. Henry D.
Locke, Vice-President, will discuss the operation of this department.

Time: At 4:00 P.M. Thursday, Dec. 27, and Friday, Dec. 28.

Place: Meet at Information Desk, Copley-Plaza Hotel.

\section{Keystone Custodian Funds}

Description: Inspection of the flow of work and the physical facilities used by staff in managing a $\$ 200$ million investment fund. Followed by a discussion of fund management and question period.

Time: 10:00 A.M. and 3:00 P.M. on Friday, Dec. 28.

(Please register for this tour at the Statler Information Desk by 1:00 P.M. Thursday, Dec. 27.)

Place: Meet at Information Desk at Statler Hotel.

\section{Key to Abbreviations}

Names of associations meeting in joint sessions are indicated as follows in the official program.

A.E.A. - American Economic Association

A.F.A. - American Finance Association

A.M.A. - American Marketing Association

A.S.A. - American Statistical Association

E.S. - Econometric Society

I.M.S. - Institute of Mathematical Statistics

I.R.R.A. - Industrial Relations Research Association

A.A.U.T.I. - American Association of University Teachers of Insurance

C.E.A. - Catholic Economic Association

B.S. (ENAR) - Biometrics Society, Eastern North American Region

A.F.E.A. - American Farm Economics Association

P.A.A. - Population Association of America

B.S.A.S. - Boston Security Analysts Society

A.S.Q.C. (NER) - American Society for Quality Control, New England Region

R.S.S. - Rural Sociological Society

S.W.R.G. - Social Work Research Group

A.S.S. - American Sociological Society

S.A. - Society of Actuaries

E.H.A. - Economic History Association

A.P.H.A. (SS) - American Public Health Association (Statistics Section) 


\section{ASSOCIATION OFFICERS}

\section{AMERICAN ECONOMIC ASSOCIATION}

President: John H. Williams, Federal Reserve Bank of New York Vice-Presidents: Corwin D. Edwards, Federal Trade Commission Donald H. Wallace, Princeton University

Secretary-Treasurer: James Washington Bell, Northwestern University Managing Editor: Paul T. Homan, University of California at Los Angeles Ran Economic

Review

Legal Counsel: John E. Walker, Washington, D. C.

Executive Committee:

The Officers and

Past Presidents: Howard S. Ellis, University of California Frank H. Knight, University of Chicago

Elected Members: Arthur F. Burns, Columbia University

Paul A. Samuelson, Massachusetts Institute of Technology Lester V. Chandler, Princeton University Robert A. Gordon, University of Californi John B. Condliffe, University of Californi Albert G. Hart, Columbia University

Editorial Board: Moses Abramovitz, Stanford University William J. Fellner, University of California Milton Friedman, University of Chicago Richard A. Musgrave, University of Michiga Lloyd G. Reynolds, Yale University

\section{AMERICAN FINANCE ASSOCIATION}

President: Raymond J. Saulnier, Barnard College, Columbia University

Vice-Presidents: Money and Banking; Roy L. Reierson, Bankers Trust

Company Investments; Wilford J. Eiteman, University of Michigan

Investments; Wilford J. Eiteman, University of Michigan
Business Finance; Charles C. Abbott, Harvard University Insurance; William C. Greenough, Teachers Insurance \& Annuity Association

Public Finance; Harold M. Groves, University of Wiscon-

International Finance; Arthur R. Upgren, University of Minnesota

Secretary-Treasurer: Edward E. Edwards, Indiana University

Editor: Marshall D. Ketchum, University of Chicago

Journal of Finance

Associate Editor:

Raymond J. Saulnier, Columbia University

Howard R. Bowen, University of Illinois

Benjamin H. Beckhart, Columbia Universit

Neil H. Jacoby, University of California at Los Angeles

Lewis A. Froman, Russell Sage College

Editorial Board: Raymond J. Saulnier, Columbia Univeristy

Pearson Hunt, Harvard University
Jules I. Bogen, New York Universit
AMERICAN MARKETING ASSOCIATION

President: George H. Brown, University of Chicago

Vice-Presidents: Robert J. Eggert, Ford Motor Company Thomas G. MacGowan, The Firestone Tire \& Rubbe Company

Reavis Cox, University of Pennsylvania

Secretary: Ira D. Anderson, Northwestern University

Treasurer: Donald E. West, McCall Corporation

Directors: Harold P. Alspaugh, H. J. Heinz Company Henry G. Baker, University of Georgia Robert T. Browne, Pillsbury Mills, Inc. Delbert J. Duncan, University of California B. F. Lynip, Jr., C \& H Sugar Refining Corporation B. F. Lynip, Jr, $C$ Ha Hugh H. MacMillan, The Detroit Free Press

Dean M. Prather, A. C. Nielsen Company of Canada, Ltd. Charles W. Smith, McKinsey \& Company

Everett R. Smith, MacFadden Publications, Inc.

Hugh G. Wales, University of Illinois

Wilford I. White, Department of Commerce

Editorial Board: Editor-in-Chief; E. R. Hawkins, Johns Hopkins University The Journal of Marketing Managing Editor; Albert W. Frey, Dartmouth College Marketing Research Editor; James H. Lorie, Federal Reserve System

Book Review Editor; Charles J. Dirksen, University of Santa Clara

Steuart Henderson Britt, Needham, Louis \& Brorby, Inc.

Orin E. Burley, University of Pennsylvania

Lincoln Clark, University of Tennessee

Joel Dean, Columbia University

Morris H. Hansen, Bureau of the Census

George L. Mehren, University of California

\section{AMERICAN STATISTICAL ASSOGIATION}

President: Lowell J. Reed, Johns Hopkins University and Hospital President-Elect: Aryness Joy Wickens, U. S. Bureau of Labor Statistics Past President: Samuel S. Wilks, Princeton University

Vice-Presidents: Dorothy S. Brady, U. S. Bureau of Labor Statistics Morris H. Hansen, U. S. Bureau of the Census

Secretary-Treasurer: Samuel Weiss, U. S. Burea u of Labor Statistics

Directors: Gertrude M. Cox, University of North Carolina W. Edwards Deming, U. S. Bureau of the Budget Cyril H. Goulden, Central Experiment John W. Tukey, Princeton University Ralph J. Watkins, Dun \& Bradstreet, Inc.

Council: C. M. Armstrong, New Y ork State Department of Education W. S. Brush, Consolidated Edison Company, New York Jerome Cornfield, National Cancer Institute Lester R. Frankel, Dun \& Bradstreet, Inc. Paul G. Hoel, University of California H. L. Jones, Illinois Bell Telephone Company 
T. J. Mills, Arlington, Virginia

Frederick Mosteller, Harvard University

P. R. Rider, Washington University

E. R. Stockton, University of Texas

W. Allen Wallis, University of Chicago

he American

Statistician

Journal of the

Sylvia Weyl, National Office, ASA

American Statistical

Association Editor: W. Allen Wallis, University of Chicago

\section{ECONOMETRIC SOCIETY}

President: R. G. D. Allen, London School of Economics

Vice-President: Paul A. Samuelson, Massachusetts Institute of Technology

Secretary: William B. Simpson, Cowles Commission

Treasurer: Alfred Cowles, Cowles Commission

Council: The Officers and:

Constantino Bresciani-Turroni, Banco di Roma, Italy Colin Clark, Bureau of Industry, Australia

Griffith C. Evans, University of California at Berkeley

John R. Hicks, Nuffield College, England

Tjallin. Hicks, Nuffeld College, England

Tjalling C. Koopmans, Cowles Commission and UniSimor

Simon Kuznets, University of Pennsylvania

Herma

Ditor:

Econometrica

Managing Editor: W. B. Simpson, University of Chicago

\section{INSTITUTE OF MATHEMATIGAL STATISTICS}

President: P. S. Dwyer, University of Michigan

President-Elect: M. A. Girshick, Stanford University

Secretary-Treasurer: C. H. Fischer, University of Michigan

Editor: T. W. Anderson, Columbia University

The Annals of

Statistics

Council: W. G. Cochran, Johns Hopkins University

C. Eisenhart, Bureau of Standards

Harold Hotelling, University of North Carolina

E. L. Lehmann, Princeton University

- David Blackwell, Stanford University

W. G. Madow, University of Illinois

F. C. Mosteller, Harvard University

L. J. Savage, University of Chicago

Harold Cramér, University of Stockholm

A. M. Mood, RAND Corporation

Jerzy Neyman, University of California

S. S. Wilks, Princeton University
INDUSTRIAL RELATIONS RESEARCH ASSOGIATION

President: William M. Leiserson, Washington, D. C.

Secretary

Executive Board: E. Wight Bakke Yale University

Solomon Barkin, Textile Workers Union of America

Phillips Bradley, Syracuse University

Ewan Clague, Bureau of Labor Statistics

Nathan P. Feinsinger, University of Wisconsin

Nathan P. Feinsinger, University of Wisconsin

Frederick H. Harbison, University of Chicago

Arthur Kornhauser, Wayne University

Clark Kerr, University of California at Berkeley

Richard A. Lester, Princeton University

Lois MacDonald, New York University

George W. Taylor, University of Pennsylvania

William F. Whyte, Cornell University

Legal Counsel: Alexander H. Frey, University of Pennsylvania

Editor: L. Reed Tripp, University of Wisconsin

\section{AMERICAN ASSOCIATION OF UNIVERSITY TEACHERS OF} INSURANCE

President: Erwin A. Gaumnitz, University of Wisconsin

Vice-President: C. M. Kahler, University of Pennsylvania

Secretary-Treasurer: J. Edward Hedges, Indiana University

Executive Committee: J. Anderson Fitzgerald, University of Texas

Charles C. Center, University of Wisconsin

Charles C. Center, University of Olsahoma

Clayton G. Hale, The Hale \& Hale Company

\section{CATHOLIC ECONOMIC ASSOGIATION}

President: John H. Sheehan, University of Notre Dame

Vice-Presidents: Rev, Raymond J. Miller, C.SS.R., St. John's Church, Carlisle, Kentucky

Rev. Louis Baska, O.S.B., St. Benedict's College

Secretary-Treasurer: Sister M. Yolande, O.F.S., College of St. Tere

Executive Committee: Dr. Joseph Solterer, Georgetown De University

Editor:

Francis J. Brown, De Paul University

Social Economy

Associate Editors: Sister Mary Ignatius, S.N.D., Notre Dame College

Paul Montavon, Quincy College

Helen Potter, Seton Hill College

Rafael Alonso Trieto, Monterey, Mexico

\section{SEE HISTORIC BOSTON AND VIGINITY}

HERTZ DRIV-UR-SELF SYSTEM is providing an Auto Rental Service to convention delegates. Cars are available at the Motor Mart Garage which is directly behind the Statler Hotel.

Telephone: HUbbard 2-0800 


\section{$\sqrt{ } \quad A$ check list of some Macmillan economics texts}

LABOR and INDUSTRIAL RELATIONS

Richard Lester

1951-\$4.25

PROBLEMS of LABOR Glenn Miller

$1951-\$ 5.00$

BUSINESS CYCLES

D. Hamberg

$1951-\$ 5.00$

ECONOMIC DYNAMICS

William Baumol

$1951-\$ 5.00$

AMERICA'S ECONOMIC GROWTH, 3rd Ed. Fred Shannan 1951-\$6.00 MONEY, TRADE and ECONOMIC GROWTH
in honor of John H. Williams

ECONOMIC RESOURCES \& POLICIES of the SOUTH

C. Hoover and B. Ratchford $\quad 1951-\$ 5.50$

INTRODUCTION to SOCIAL SCIENCE, 2 vols. Atteberry, Auble, Hunt, Masiko $\$ 5.00$ each vol.

THE INTERNATIONAL ECONOMY

P. T. Ellsworth

PRINCIPLES of BUSINESS \& the FEDERAL LAW Franklin Cook $1951-\$ 5.50$

The STRUCTURE of AMERICAN INDUSTRY Walter Adams $1950-\$ 4.75$

To be published in the spring-A New Text...

THE ECONOMIC SYSTEM: An Analysis of the Flow of Economic Life

E. T. Weiler

University of Illinois

The Macmillan Company 60 Fifth Avenue, N.Y. 11 


\section{national Bureau of Economic Research}

\section{BROADWAY NEW YORK 23, N.Y.}

\section{Current Books}

What Happens during Business Cycles: A Progress Report 492 pages
$48+$ tables WESLEY C. MITCHELL 7 charts appendices
Inventories and Business Cycles,
with Special Reference to Manufacturers' Inventories
MOSES ABRAMOVITZ

672 pages $116+$ tables MOSES ABRAMOVITZ 7 appendices

Conference on Business Cycles Eleven papers presented and ensuing discussion at Conference on Business Cycles, November $\underset{\$ 48.00}{1949}$
$\$ 48$ pages Studies in Income and Wealth, Volume Thirteen Ten papers on size distribution of income 608 pages

Studies in Income and Wealth, Volume Fourteen Seven papers on wealth 288 pages

Deterioration in the Quality of Foreign Bonds Issued in the United States, $1920-1930$
1ISE

112 pages

19 tables

The Transportation Industries, 1889-1946:

A Study of Output, Employment, and Productivity 304 pages 64 tables $\underset{25 \text { charts }}{\text { HARER }} 9$ appendices

Urban Real Estate Markets: Characteristics and Financing 208 pages

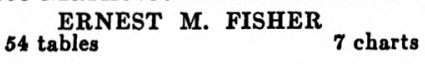

The Nature and Tax Treatment of Capital Gains and Losses 676 pages 98 tables LAWRENCE $\mathrm{H}$. SELTZER

Corporate Income Retention, 1915-43

142 pages

\section{SCHEDULE OF MEETINGS}

Wednesday, December 26, 1951

12:00 Noon STATLER Parlor F $1: 20-3: 20$ P.M.
COPLEY-PLAZA State Suite

Chairman:

Papers:
Luncheon Meeting of the Executive Committee

American Economic Association

\section{Contributed Papers-I}

Institute of Mathematical Statistics

S. B. Littauer, Columbia University

TWO RANK ORDER TESTS WHICH ARE MOST POWERFUL AGAINST SPECIFIC PARAMETIRC ALTERNATIVES

Milton E. Terry, Jr., Virginia Polytechnic Institute.

PARTIALLY BALANCED DESIGNS WITH

$$
k>\gamma=3
$$

R. C. Bose and W. H. Clatworthy, University of North Carolina at Chapel Hill.

SOME OBSERVATIONS ON THE F-TEST IN ANALYSIS OF VARIANCE

S. N. Roy, University of North Carolina at Chapel Hill

THE NEYMAN-PEARSON LEMMA FACTOR FUNCTIONS

L. M. Court, American Power Jet Company THE PROBABILITY OF A CORRECT RANKING (PRELIMINARY REPORT)

Robert E. Bechhofer, Columbia University A NON-PARAMETRIC ANALOGUE BASED
UPON RANKS OF ONE-WAY ANALYSIS OF VARIANCE

William Kruskal, University of Chicago

A SERIES OF GROUP DIVISIBLE DESIGNS FOR TWO-WAY ELIMINATION OF HETERO-

S. S. Shrinkhande, University of Kansas

A TEST OF THE UNIFORMITY OF THE CIRCULAR DISTRIBUTION (PRELIMINARY REPORT)

J. Arthur Greenwood, Manhattan Life Insurance Company and David Durand, National Bureau of Economic Research

See Publications at Booth in Exhibition Hall 
A METHOD FOR LIMIT THEOREMS IN MARKOV CHAINS

T. E. Harris, The RAND Corporation

ON TESTS OF CERTAIN HYPOTHESES ABOUT MULTIVARIATE NORMAI POPULATIONS. (BY TITLE).

S. N. Roy, University of North Carolina at Chapel Hill.

AN INEQUALITY FOR ORTHOGONAL AR. RAYS OF STRENGTH 2. (BY TITLE)

S. S. Shrinkhande, University of Kansas

2:30 P.M. STATLER

International Trade Theory American Economic Association

Ballroom

Chairman: R. B. Bryce, Department of Finance, Ottawa, Canada

Papers: THE PRESENT STATE OF THE THEORY OF INTERNATIONAL VALUES

Jacob Viner, Princeton University

HAS THE MODERN THEORY OF ECONOMIC TRENDS CONTRIBUTED TO THE IMPROVEMENT OF INTERNATIONAL ECONOMIC RELATIONS?

Arthur Smithies, Harvard University

Discussion: G. A. Elliott, University of Toronto

J.J. Polak, International Monetary Fund

2:30 P.M.

\section{STATLER}

Georgian Room

Chairman: Theodore W. Schultz, University of Chicago

Papers: APPRAISING THE DEMAND FOR AMERICAN AGRICULTURAL OUTPUT

Elmer J. Working, University of Illinois

AMERICAN AGRICULTURAL POLICY DURING REARMAMENT

Karl Brandt, Food Research Institute

Discussion: William H. Nicholls, Vanderbilt University

- Kenneth H. Parsons, University of Wisconsin

\section{2:30 P.M.}

STATLER

Parlor A

\section{Investments}

American Finance Association

Chairman: Wilford J. Eiteman, University of Michigan

Papers: IMPACT OF BUSINESS CONDITIONS ON INVESTMENT POLICIES

Harold X. Schreder, Distributors Group, Inc. INVESTMENT PSYCHOLOGY SINCE KOREA

Douglas H. Bellemore, Boston University

SHORT- AND LONG-TERM CAPITAL REQUIREMENTS

Elmer C. Bratt, Lehigh University

Discussion: Jacob O. Kamm, Baldwin-Wallace College George L. Leffler, Pennsylvania State College

2:30 P.M. STATLER
4th Floor

2:30 P.M. STATLER Parlor C

\section{Contributed Papers Econometric Society}

Chairman: John Chipman, Harvard University

Papers: RELATION OF LABOR REQUIREMENTS TO OUTPUT

D. Suits, University of Michigan

THEORIES OF LOCATION AND TRADE, INTERNATIONAL AND INTERREGIONAL

W. Isard and M. T. Peck, Harvard University

Discussion: General Discussion from the Floor

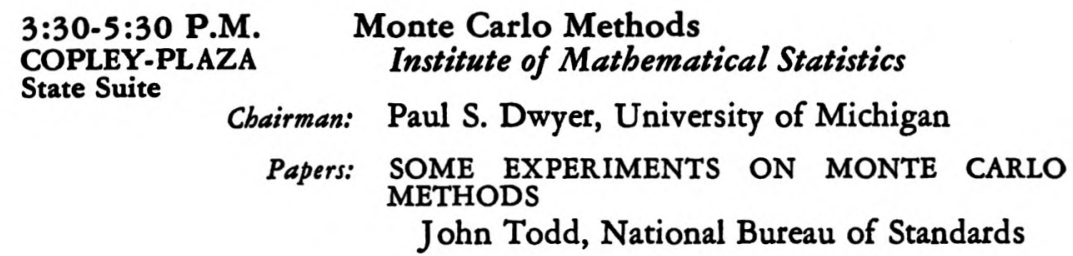


EMPIRICAL SAMPLING DISTRIBUTIONS

Dan Teichroew, University of North Carolina

Discussion: R. L. Anderson, University of North Carolina William Feller, Princeton University

8:00 P.M. STATLER Ballroom

\section{American Foreign Aid Programs} American Economic Association

Chairman: Gottfried Haberler, Harvard University

Papers: EUROPEAN RECOVERY AND THE PROBLEMS AHEAD

Richard M. Bissell, Jr., Deputy Director, Mutual Security Agency; and (on leave)

Massachusetts Institute of Technology

RAW MATERIALS, REARMAMENT, AND ECONOMIC DEVELOPMENT

Edward S. Mason, Harvard University

Discussion: Don D. Humphrey, Duke University Walter S. Salant, Council of Economic Advisers

8:00 P.M. STATLER

Georgian Room

Governmental Policy on Business Practices American Economic Association

Chairman: Theodore J. Kreps, Stanford University

Papers: ANTI-TRUST POLICY DURING REARMAMENT Corwin D. Edwards, Federal Trade Commission

GOVERNMENT AID TO BUSINESS EXPANSION Edward C. Welsh, Reconstruction Finance Corporation

Discussion: Melvin de Chazeau, Cornell University Kermit Gordon, Williams College

8:00 P.M. STATLER 4th Floor

Developments in Input-Output Analysis Econometric Society

Cbairman: Milton Friedman, University of Chicago

Paperx THE 1947 INPUT-OUTPUT TABLE

D. Evans, M. Hoffenberg, U. S. Bureau of Labor Statistics

A DYNAMIC MODEL

J. I. Holley and G. Dantzig, U. S. Department of the Air Force
Discussion: John Chipman, Harvard University.

B. Klein, Council of Economic Advisers

W. A. Wallis, University of Chicago

8:00 P.M. COPLEY-PLAZ

Time Series Analysis

COPLEY-PL

Econometric Society

Chairman: Harold M. Somers, University of Buffalo

Papers: ECONOMIC TIME SERIES AND THE TESTING OF HYPOTHESES

G. Orcutt, Harvard University

AUTOCORRELATION OF THE DISTURBANCES IN ECONOMIC BEHAVIOR EQUATIONS

J. Gurland, Cowles Commission

Discussion: N. Georgescu-Roegen, Vanderbilt University W. C. Hood, University of Toronto E. J. Working, University of Illinois

Bringing the Library to the Student

\section{OUTSIDE READINGS} in ECONOMICS

\section{HESS, GALLMAN, \\ RICE, and STERN}

Wharton School, University of Pennsylvania

Significant-each article a definite contribution to student understanding. Average length of articles: nine pages

Up-to-date-74\% published since 1945

Inexpensive -877 pages, hard cover, $\$ 2.95$

THOMAS Y. CROWELL COMPANY

432 FOURTH AVENUE NEW YORK 16, N. $y$. 
aаке(

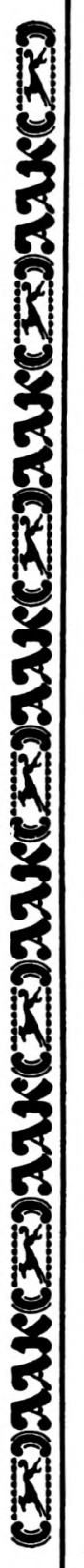

NEW AND DIFFERENT

ECONOMICS

An Introductory Analysis of

the Level, Composition, and

Distribution of Economic Income

by Bruce Winton Knight and

Lawrence Gregory Hines of DARTMOUTH COLLEGE

Avoiding the limitations of any one "approach" to economic theory and policy, whether pre-Keynesian, postKeynesian, or Institutional, this elementary text is distinguished by its balanced use of all three approaches. For the introductory course it will prove eminently teachable because it is so very readable.

Ready in April.

Examination copies on request.

ALFRED $\cdot A \cdot$ KNOPF, Publisher

501 Madison Avenue, New York 22

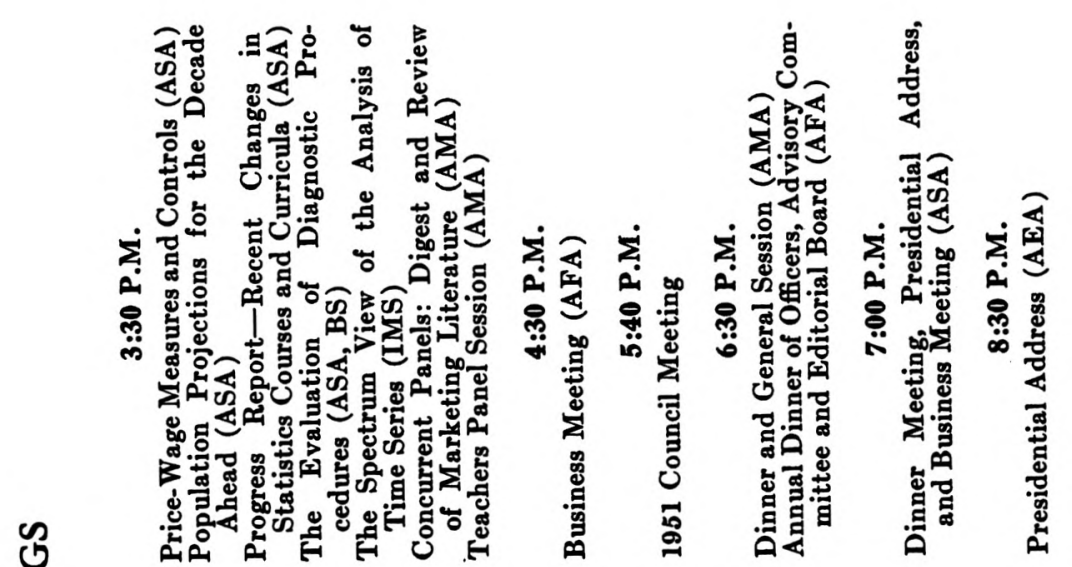

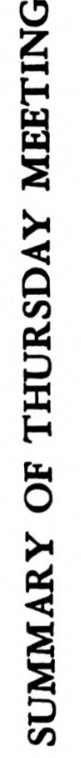
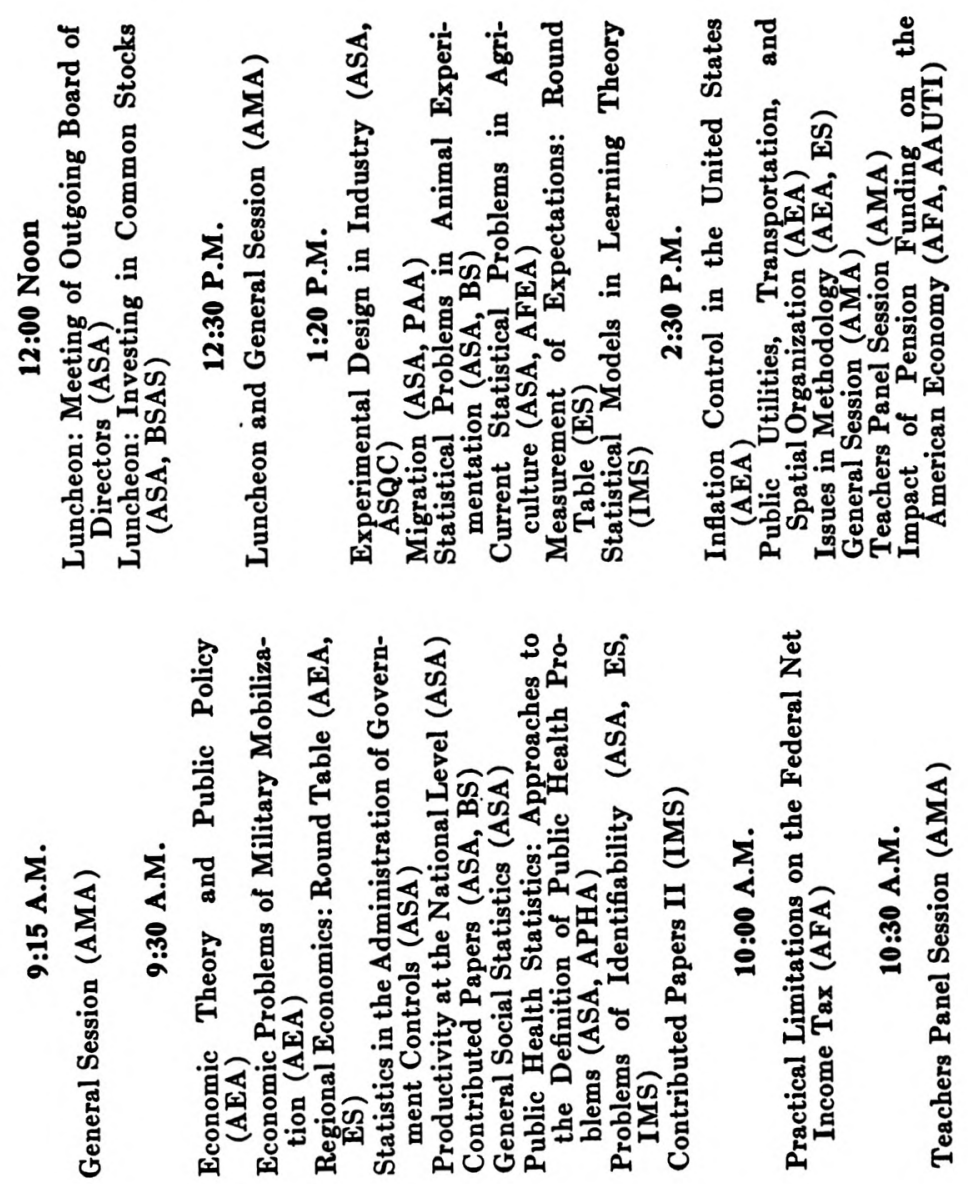


\section{SCHEDULE OF MEETINGS}

\section{A CHECK LIST OF IRWIN TEXTS IN MARKETING}

\section{SALES MANAGEMENT}

Policies and Proceduress
By D. M. Phelps, University of Michigan

SALESMANSHIP Principles and Methods
By C. A . Pederson, Stanford University, and
M. D. Wright, San Jose State College

WRITING FOR BUSINESS

Selected Articles on Buriness Communication

y C. W. Winkinson, Michigan State College

C. H. Menning, University of Alabama, and

\section{MARKETING}

By C. F. Phillips, Bates College, and D. J.
Duncan, University of California

MARKETING BY MANUFACTURERS

Revised Edition By C. F. Phillips, Bates College

THEORY IN MARKETING

By Reavis Cox, University of Pennsylvania,
and Wroe Alderson, Alderson \& Sessions, Inc.

PLANNING THE PRODUGT

By D. M. Phelps, University of Michigan

\section{RETAILING}

Principles and Methods-Third Edition

By D. J. Duncan, University of California,

PROCUREMENT

Principles and Cases
By Howard T. Lewis, Harvard University

ADVERTISING

Theory and Practice-Third Edition
By Charles H. Sandage, University of Illinois ADVERTISING

Text and Cases By Neil H. Borden, Harvard University

THE ECONOMIC EFFECTS OF

ADVERTISING

By Neil H. Borden, Harvard University

ADVERTISING IN OUR ECONOMY

By Neil H. Borden, Harvard University
Thursday, December 27, 1951

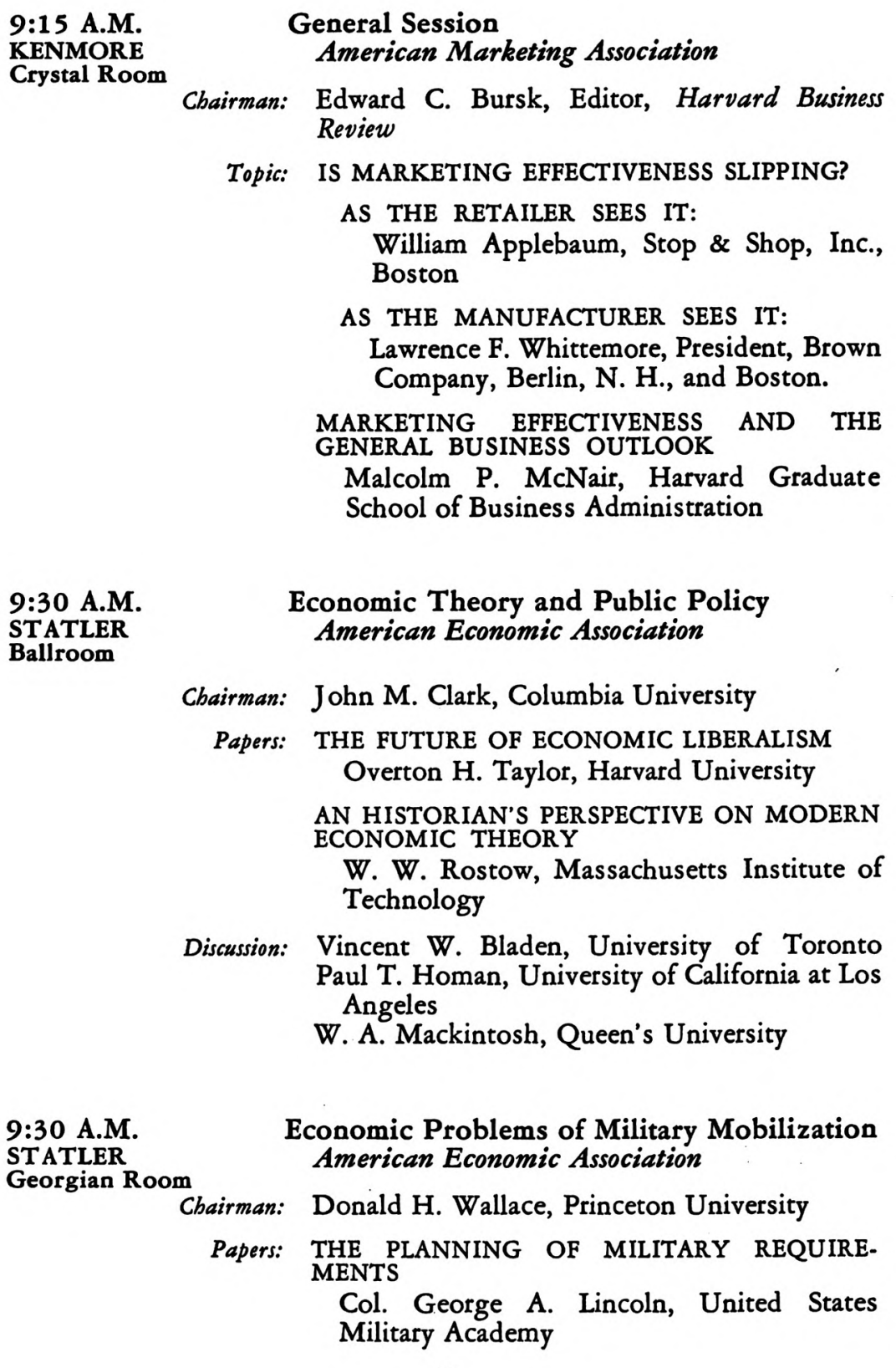


PROCUREMENT POLICIES-WORLD WAR II TODAY

John Perry Miller, Yale University

Discussion: Harry E. Howell, New York City J. Philip Wernette, University of Michigan

9:30 A.M.

STATLER
Parlors $A$ and $B$

Regional Economics: Round Table Joint Session: A.E.A., E.S.

Chairman: Calvin B. Hoover, Duke University

Paper: A DISCUSSION OF THE SPATIAL ASPECTS O THE STRUCTURE AND FUNCTIONING OF AN ECONOMIC SYSTEM Rutledge Vining, University of Virginia

Discussion: Edgar Dunn, University of Florida Edgar M. Hoover, Council of Economic Advisers

Stefan Robock, Tennessee Valley Authority

Harry S. Schwartz, Federal Reserve Bank of San Francisco

Nathaniel Wollman, University of New Mexico

9:30-11:30 A.M. COPLEY-PLAZA

Statistics in the Administration of Government Controls

American Statistical Association

Chairman: Lester S. Kellogg, Deere \& Company

Papers: THE GOVERNMENT'S STATISTICAL PROGRAM UNDER EMERGENCY CONDITIONS

Donald C. Riley, Division of Statistical Standards, Bureau of the Budget

GOVERNMENT STATISTICAL REQUESTS UNDER THE DEFENSE PROGRAM

Theodore E. Veldfort, Manager, Copper \& Brass Research Association, New York

Discussion: Adolph G. Abramson, SKF Industries Earle Constantine, National Association of Hosiery Manufacturers

\section{9:30-1 1:30 A.M. . Productivity at the National Level \\ COPLEY-PLAZA American Statistical Association}

Oval Room

Chairman: Solomon Fabricant, New York University

Papers: PRODUCTIVITY IN THE SOVIET UNION Irving H. Siegel, 20th Century Fund, New York
PRODUCTIVITY IN PUERTO RICO

Simon Rottenberg, University of Puerto Rico

INTERNATIONAI COMPARISONS OF REAL PER CAPITA INCOME

J. B. D. Derksen, United Nations Statistical Office

Discussion: Henry G. Aubrey, New School for Social Research

Alexander Gerschenkron, Harvard University

\section{9:30-11:30 A.M. Contributed Papers}

COPLEY.PLAZA

Copley Club

Chairman: W.J. Youden, National Bureau of Standards

Papers: TYPE OF RETURNS FROM WAVES OF MAII QUESTIONNAIRES IN TWO NATIONAL MAGAZINE READERSHIP SURVEYS

Walter T. Federer, Cornell University, and Robert K. McMillan, National Analysts, Inc.

THE MULTIPLE SAMPLING OF ATTRIBUTES

Douglas S. Robson, Cornell University, and A. J. King, National Analysts, Inc.

ANALYSIS OF PARTIALLY BALANCED INCOMPLETE BLOCK DESIGNS ILLUSTRATED ON THE SIMPLE RECTANGULAR LATTICE

K. R. Nair, Forest Research Institute, India

LATINIZED RECTANGULAR LATTICES

Boyd Harshbarger, Virginia Polytechinc Institute

\section{9:30-11:30 A.M.} COPLEY-PLAZA

Parlor B

Cbairman: Harry Alpert, Division of Statistical Standards, Bureau of the Budget

Papers: PROBLEMS AND METHODS IN FEDERAL STATISTICS ON EDUCATION

Herbert S. Conrad, U. S. Office of Education

THE CENTRAL REGISTER AS A DEVICE FOR PRODUCING BETTER STATISTICS AS THE BASIS FOR UNDERSTANDING AND TREATING JUVENILE DELINQUENCY

Sophia M. Robison, New York School of Social Work 
THE NATIONAL PRISONER STATISTICS PROGRAM

Henry Coe Lanpher and James C. McCafferty, Bureau of Prisons, Department of Justice

Discussion: Francis G. Cornell, University of Illinois Albert Morris, Boston University Edward E. Schwartz, U. S. Children's Bureau

9:30-11:30 A.M. Public Health Statistics: Approaches to the COPLEY-PLAZA State Suite

\section{Definition of Public Health Problems}

Joint Session: A.S.A., A.P.H.A. (S.S.)

Chairman: Paul M. Densen, University of Pittsburgh

Papers: WHAT IS A PUBLIC HEALTH PROBLEM Morton Levin, New York State Department of Health

THE FAMILY AS A UNIT IN PUBLIC HEALTH RESEARCH

Margaret Merrell, Johns Hopkins University THE PROBLEM OF DEFINING A MEDICAL SERVICE AREA

Isidore Altman, U. S. Public Health Service

\section{9:30-11:30 A.M. COPLEY-PLAZA} Sheraton RoOm

Chairman: Paul Samuelson, Massachusetts Institute of Technology

Papers: IDENTIFIABILITY AND CONSISTENT ESTI. MABILITY OF STRUCTURAL RELATIONS Jerzy Neyman, University of California at Berkeley

SYSTEMS OF NON-LINEAR STOCHASTIC DIF. FERENCE EQUATIONS

Herman Rubin, Stanford University

NECESSARY AND SUFFICIENT CONDITIONS FOR CONSISTENT ESTIMABILITY

Joseph L. Hodges, Jr., University of Chicago

Discussion: L. Hurwicz, University of Illinois

Terry A. Jeeves, University of California at Berkeley

C. M. Stein, University of Chicago
9.30-11:30 A.M. Contributed Papers II

COPLEY-PLAZA Institute of Matbematical Statistics

Chairman: To be announced

Papers: THE DISTRIBUTION OF THE RANGE IN SAMPLES FROM A COMPOUND NORMAL SAMPLES FROM

Kenneth $H$. Kramer, Youngstown Sheet and Tubing Company

ON THE OPERATING CHARACTERISTICS OF CERTAIN QUALITY CONTROL TESTS

John E. Walsh, U. S. Naval Ordnance Station, Pasadena, California

OPERATING CHARACTERISTICS OF THE CONTROL CHART FOR SAMPLE MEANS

Edgar P. King, Carnegie Institute of Technology

JOINT SAMPLING DISTRIBUTIONS OF THE MEANS AND STANDARD DEVIATION FOR FREQUENCY FUNCTIONS OF THE SECOND KIND

Melvin D. Springer, U. S. Naval Ordnance, Indianapolis, Indiana

STATISTICAL THEORY OF DROUGHTS

E. J. Gumbel, Consultant, Stanford University

SOME THEOREMS RELEVANT TO LIFE TEST. ING

Milton Sobel and Benjamin Epstein, Wayne University

SOME TESTS BASED ON THE FIRST $\gamma$ OR DERED OBSERVATIONS DRAWN FROM AN EXPONENTIAL DISTRIBUTION

Benjamin Epstein and Milton Sobel, Wayne University

A METHOD OF REDUCING THE TIME RE. AUIRED TO COMPLETE CERTAIN FATIGUE TESTS

Leonard G. Johnson, Research Laboratories Division, General Motors Corporation, Detroit, Michigan

ON THE MULTIVARIATE POISSON DISTRIBU. TION

Henry Teicher, Purdue University.

FORMULAS FOR APPROXIMATING THE HYPERGEOMETRIC AND BINOMIAL BY THE POISSON DISTRIBUTION

I. W. Burr, Purdue University 
DISTRIBUTION OF RANGES FROM AN ARBITRARY DISCRETE UNIVERSE (BY TITLE)

I. W. Burr, Purdue University

10:00 A.M Parlor C

\section{0:30 A.M. KENMORE} Silver Room

\section{Teachers Panel Session} American Marketing Association

Chairman: Richard M. Clewett, Northwestern University

Topic: GENERAL MARKETING

Panel Participants: To be announced

12:00 Noon COPLEY-PLAZA Room 131

Luncheon: Meeting of Outgoing Board of Directors American Statistical Association

12:00-3:20 P.M. Luncheon: Investing in Common Stocks COPLEY.PLAZA Joint Session: A.S.A., B.S.A.S.

Cbairman: Robert J. Wilkes, Scudder, Stevens \& Clark

Papers: THE PRINCIPLES OF FORMULA INVESTING Robert A. Warren, Keystone Custodian Funds, Inc.

COMMON STOCKS AND LIFE INSURANCE COMPANIES

Sherwin C. Badger, New England Mutual Life Insurance Company

\section{Thursday}

12:30 P.M KENMORE Crystal Room

Luncheon and General Session American Marketing Association

Chairman: John Bidwell, President, New England Chapter, A.M.A and Manager, Marketing Research Division, Dewey \& Almy Chemical Company, Cambridge, Massachusetts

Topic: HOW LONG WILL THE FREE MARKET BE FREE?

Emerson P. Schmidt, Chief Economist, U. S. Chamber of Commerce, Washington, D. C.

\section{1:20-3:20 P.M. Experimental Design in Industry COPLEY-PLAZA Joint Session: A.S.A., A.S.Q.C. (NER)}

Chairman: Dorian Shanin, Hamilton Standard Division, United Aircraft Corporation

Papers: AN INDUSTRIAL EXPERIMENT IN PAPER SATURATION

Warren Purcell, Brown Company

USE OF STATISTICAL PRINCIPLES IN FACTORY TROUBLE SHOOTING

Leonard A. Seder, Gillette Safety Razor

Discussion: John Riordan, Department of the Air Force John G. Rutherford, The Glen L. Martin Company

Louis G. Young, Consultant

\section{1:20-3:20 P.M. Migration \\ COPLEY-PLAZA Joint Session: A.S.A., P.A.A. \\ Sheraton Room}

Chairman: Henry S. Shryock, Jr., U.S. Bureau of the Census

Papers: INTRASTATE MIGRATION FOR WASHINGTON $1935-40$

Calvin F. Schmid, University of Washington, and M. J. Griswold, Wayne University

INTRASTATE MIGRATION IN THE TENNESSEE VALIEY AREA, 1935-40

John Folger, Maxwell Air Force Base

INTERSTATE MIGRATION IN NEW ENGLAND, 1935-40

R. G. Burnight, University of Connecticut 
1:20-3:20 P.M. COPLEY-PLAZA Copley Club

Statistical Problems in Animal Experimentation

Joint Session: A.S.A., B.S. (ENAR)

Chairman: Earl L. Green, Ohio State University

Papers: SOME STATISTICAL ASPECTS OF RESEARCH USING RADIOACTIVE ISOTOPES AND X-RAYS A. E. Brandt, Atomic Energy Commission

AN APPLICATION OF FACTOR ANALYSIS TO THE SYSTEMATICS OF THE GENUS KALOTERMES

C. P. Stroud, University of Chicago BIO-ASSAY WITH THE LATIN SQUARE-THE CHOICE OF AN ERROR TERM

Jerome Cornfield, National Cancer Institute

\section{HARPER \& BROTHERS}

\section{Publishers}

EXTENDS GREETINGS

TO TEACHERS

OF ECONOMICS AND

\section{BUSINESS ADMINISTRATION}

AND CORDIALLY INVITES THEM

TO VISIT THE EXHIBIT

OF HARPER BOOKS

IN THE FOYER OF THE GRAND BALL ROOM STATLER HOTEL

Ivan M. Lee, Giannini Foundation of Agri-

\section{1:20-3:20 P.M. Current Statistical Problems in Agriculture COPLEY.PLAZA Joint Session: A.S.A., A.F.E.A. \\ Foyer \\ Chairman: F. F. Hill, Cornell University}

Papers: MEASURING THE SHIFTING STRUCTURE OF AMERICAN AGRICULTURE

Orris V. Wells, Bureau of Agricultural Economics, U. S. Department of Agriculture

A CRITICAL EVALUATION OF AVAILABLE AGRICULTURAL STATISTICS cultural Economics, University of California

Discussion: Harold G. Halcrow, University of Connecticut O. C. Stine, 20th Century Fund, New York

\section{1:20 P.M. COPLEY-PLAZA Parlor C}

\section{Measurement of Expectations: Round Table} Econometric Society

Chairman: Robert Bishop, Massachusetts Institute of Technology

Paper: THE MEASUREMENT OF EXPECTATIONS F. Modigliani, University of Illinois

Discussion: W. Baumol, Princeton University G. Katona, University of Michigan C. Kaysen, Harvard University

A. Kisselgoff, Bank of New York and Fifth Avenue Bank 


\section{Why Are We the Economists' Book Shop?}

\section{because}

1. WE PUBLISH IMPORTANT BOOKS IN ECONOMICS

These books are intended for the economist: working, teaching or graduate student.

Some of the books we have recently published are:

Schumpeter-Imperialism and Social Classes

Malthus-Principles of Political Economy

Hart-Anticipations, Uncertainty and Dynamic Planning

Knight-Ethics of Competition

\section{WE SPONSOR THE ECONOMISTS' BOOK CLUB}

This club makes it possible for those who belong to obtain worthwhile reprints of economic classics at reduced prices. It also makes it possible to engage in a program of reprinting economic classics. These importan See the inside back cover of the December AMERICAN ECONOMIC See the inside back cover of the December $A M$
$R E V I E W$ for details of our BOOK CLUB selections.

3. WE ISSUE CATALOGUES OF OUT-OF-PRINT AND SECOND-HAND BOOKS IN ECONOMICS

Just about every worthwhile book in economics ever written comes through our shop during the course of a few years. No doubt we have catalogued many a book you have been searching for.

4. WE ISSUE CATALOGUES OF NEW BOOKS IN ECONOMICS Our catalogues list books printed here and abroad. We try to keep abreast
of all the latest books.

5. WE OFFER A COMPLETE BOOK SERVICE TO ECONOMISTS

Why not put your name on our mailing list?

\section{AUGUSTUS M. KELLEY, Inc. BOOKSELLERS AND PUBLISHERS}

31 E. 10th STREET, NEW YORK 3, N.Y.

OUR DISPLAY BOOTH HAS FULL LISTS OF OUR PUBLICATIONS; DETAILS OF THE ECONOMISTS' BOOK CLUB; AND VARIOUS CATALOGUES WHICH WE HAVE ISSUED. WE WELCOME YOUR VISIT.

State Suite

Chairman: Harold Gulliksen, Educational Testing Service, Princeton, New Jersey

Papers: A LINEAR-OPERATOR MODEL FOR LEARNING Robert R. Bush and Frederick Mosteller, Harvard University

A STATISTICAL DESCRIPTION FOR VERBAL LEARNING

George A. Miller and William J. McGill, Massachusetts Institute of Technology

APPLICATION OF A SET-THEORETICAL MODEL TO LEARNING PHENOMENA

Cletus J. Burke and W. K. Estes, Indiana University

Discussion: Leo Goodman, University of Chicago J. C. R. Licklider, Massachusetts Institute of Technology

Max A. Woodbury, Princeton University

2:30 P.M.

STATLER

Georgian Room

Chairman

Papers:

\section{Inflation Control in the United States}

American Economic Association

Edwin G. Nourse, Washington, D. C.

RECENT EXPERIENCE WITH MONETARY FISCAL MEASURES

Woodlief Thomas, Federal Reserve Board

REFLECTIONS ON A YEAR OF PRICE CONTROLS

G. Griffith Johnson, Economic Stabilization Agency

Discussion: Albert G. Hart, Columbia University

R. B. Heflebower, Northwestern University
2:30 P.M.

STATLER

Parlors A and B

Chairman:

Papers:
Public Utilities, Transportation, and Spatial Organization

American Economic Association

C. Emery Troxel, Wayne University

CRITERIA FOR THE ESTABLISHMENT OF AN OPTIMUM TRANSPORTATION SYSTEM

Ralph L. Dewey, Ohio State University

THE OPTIMUM GEOGRAPHIC SIZE OF A RATEMAKING UNIT FOR ELECTRICITY

William F. Kennedy, Santa Barbara College 
Discussion: Edmund A. Nightingale, Juniversity of Minnesota

Joseph S. Ransmeier, Dartmouth College

2:30 P.M. STATLER

Ballroom

\begin{abstract}
Issues in Methodology
Joint Session: A.E.A., E.S.

Chairman: Fritz Machlup, Johns Hopkins University

Papers: THE IMPACT ON GENERAL ECONOMICS OF MORE REALISTIC THEORIES OF THE FIRM

K. E. Boulding, University of Michigan INSTITUTIONALISM AND EMPIRICISM IN

Frank H. Knight, University of Chicago ECONOMIC THEORY AND MATHEMATICSAN APPRAISAL

Paul A. Samuelson, Massachusetts Institute of Technology

Discussion: Allan G. Gruchy, University of Maryland W. W. Leontief, Harvard University
\end{abstract}

2:30 P.M. KENMORE

General Session (continuation of luncheon session)

American Marketing Association

Topic: TELEVISION TODAY - ITS IMPACT ON PEOPLE AND PRODUCTS (An Industry-Wide Research Presented in Moving Pictures)

Robert W. McFadyen, National Broadcasting Company

\title{
2:30 P.M.
} KENMORE

\section{Teachers Panel Session}

American Marketing Association

Boston Room

Chairman: Leonard J. Bisbing, Marquette University

Topic: MARKET RESEARCH

Panel Participants: To Be Announced

2:30-4:20 P.M. Parlor C
Impact of Pension Funding on the American Economy

Joint Session: A.F.A., A.A.U.T.I.

Chairman: William C. Greenough, Teachers Insurance \& Annuity Association

Papers: SOURCES OF INCOME FOR THE AGED John J. Corson, McKinsey \& Company. INVESTMENT ASPECTS OF THE ACCUMULATION OF PENSION FUNDS

Roger Murray, Bankers Trust Company

EFFECT ON THE ECONOMY OF CHANNELING SAVINGS THROUGH PENSION FUNDS

Harry Guthmann, Northwestern University

Discussion: Raymond W. Goldsmith, R. W. Goldsmith Associates, Inc.

J. Fred Weston, University of California at Los Angeles

\section{3:30-5:30 P.M. COPLEY-PLAZA}

Sheraton Room

Chairman: Henry B. Arthur, Swift and Company

Papers: STATISTICS IN PRICE CONTROL

Gardner Ackley, Office of Price Stabilization

WAGE-PRICE RELATIONSHIPS

George Cline Smith, U. S. Chamber of Commerce

Discussion: George W. Brooks, International Brotherhood of Pulp, Sulphite and Paper Mill Workers

J. K. Galbraith, Harvard University

3:30-5:30 P.M. Population Projections for the Decade Ahead COPLEY-PLAZA

Parlor B

Chairman: Francis E. McIntyre, California Texas Oil Company, Ltd.

Papers: PROJECTING POPULATION FOR SALES FORECASTING

Margaret J. Hagood, U. S. Bureau of Agricultural Economics and Jacob S. Siegel, U. S. Bureau of the Census

THE ROLE OF POPULATION IN ECONOMIC DYNAMICS

Charles F. Roos, Econometric Institute

Discussion: John E. Hodges, Hughes Tool Company and Rice Institute

Richard M. Snyder, E. I. duPont de Nemours and Company 


\section{3:30-5:30 P.M} COPLEY.PLAZA Copley Club

Progress Report-Recent Changes in Statistics Courses and Curricula American Statistical Association

Chairman: J. E. Morton, Cornell University, on leave as Director, Survey of Statistical Operation, U. S. Bureau of Mines

Papers: DEVELOPMENTS IN EASTERN UNIVERSITIES Philip J. McCarthy, Cornell University

DEVELOPMENTS IN MID-AMERICAN UNIVERSITIES

Palmer O. Johnson, University of Minnesota DEVELOPMENTS IN WESTERN UNIVERSITIES William A. Spurr, Stanford University

Discussion: P. G. Fox, University of Wisconsin Rutledge Vining, University of Virginia S. S. Wilks, Princeton University

3:30-5:30 P.M. COPLEY-PLAZA Foyer

The Evaluation of Diagnostic Procedures Joint Session: A.S.A., B.S. (ENAR)

Chairman: John W. Fertig, Columbia University

Papers: DIAGNOSIS IN TUBERCULOSIS J. Yerushalmy, University of California DIAGNOSIS IN CANCER

John E. Dunn, National Cancer Institute DIAGNOSIS IN DIABETES

Hugh T. C. Wilkerson, U. S. Public Health Service

Discussion: Paul Meier, Philadelphia Tuberculosis Association

E. C. Hammond, American Cancer Society

W. F. Taylor, U.S.A.F. School of Aviation Medicine

3:30-5:30 P.M. COPLEY.PLAZA State Suite

The Spectrum View of the Analysis of Time Series

Institute of Matbematical Statistics

Chairman: M. A. Girshick, Stanford University

Speaker: John W. Tukey, Bell Telephone Laboratories, Inc.

Discussion: T. W. Anderson, Columbia University Guy H. Orcutt, Harvard University

3:30 P.M.

KENMORE

Crystal Room

Chairman: Cyrus S. Kauffman, President, C. S. Kauffman \& Associates, Washington, D. C

Panel Participants: WHAT INFORMATION IS AVAILABLE IN WASHINGTON AND HOW TO GET IT

Roy B. Eastin, Superintendent of Documents, U. S. Government Printing Office

Howard L. Stier, Director, Division of Statistics, National Canners Association

MARKETING USES FOR INPUT-OUTPUT DATA W. Duane Evans, U.S. Bureau of Labor Statistics

Empire Room

MARKETING RESEARCH LITERATURE

Chairman: Don Hobart, Vice President and Director of Research, Curtis Publishing Cmopany

Panel Participants: MAIN CURRENTS IN MARKETING LITERATURE

Wroe Alderson, President, Alderson \& Sessions

THE TEACHER LOOKS AT MARKETING LITERATURE

Wendell R. Smith, State University of Iowa MARKETING LITERATURE AND MARKETING PROBLEMS

Royal E. Davis, Manager of Sales Research, The Goodyear Tire \& Rubber Company

Silver Room ADVERTISING MANAGEMENT LITERATURE

Chairman: S. R. Bernstein, Editor, Advertising Age Panel Participants:

CONSUMER MARKETING

Neil H. Borden, Harvard Graduate School of Business Administration

INDUSTRIAL MARKETING Willard M. Fox, Director of Market Research, Remington Rand, Inc.

SERVICE AND INSTITUTIONAL MARKETING Richard M. Clewett, Northwestern University

3:30 P.M. KENMORE Green Room

Chairman:

Teachers Panel Session American Marketing Association

Topic: SALES MANAGEMENT 
Panel Participants: HIGHLIGHTS FROM THE 1950-1951 N.S.E. CURRICULUM SURVEY IN THE FIELD O DISTRIBUTION

Kenneth Lawyer, Western Reserve University

RESEARCH IN SALES TRAINING

J. S. Schiff, College of the City of New York CONTENT OF SALES MANAGEMENT COURSES D. M. Phelps, University of Michigan

Discussion: Discussion from the Floor

4:30 P.M.

STATLER

Business Meeting

Parlor C

American Finance Association

5:40 P.M.

COPLEY-PLAZA

1951 Council Meeting

Institute of Mathematical Statistics

Room 133

6:30 P.M.

KENMORE

Dinner and General Session

Crystal Room American Marketing Association

Chairman: Allen W. Rucker, President, The Eddy-RuckerNickels Company, Cambridge, Massachusetts,

Topic: WHAT TO DO ABOUT PRESERVING THE FREE MARKET?

Floyd A. Harper, The Foundation for Economic Education, Inc., Irvington-on-Hudson, New York

6:30 P.M. Annual Dinner of Officers, Advisory ComUniversity mittee and Editorial Board

Club American Finance Association

7:00 P.M.

COPLEY-PLAZA

Dinner Meeting, Presidential Address, and Business Meeting

American Statistical Association

Speaker: Lowell J. Reed, Johns Hopkins University

8:30 P.M STATLER

Presidential Address

American Economic Association

Chairman: Frank H. Knight, University of Chicago

Speaker: John H. Williams, Harvard University

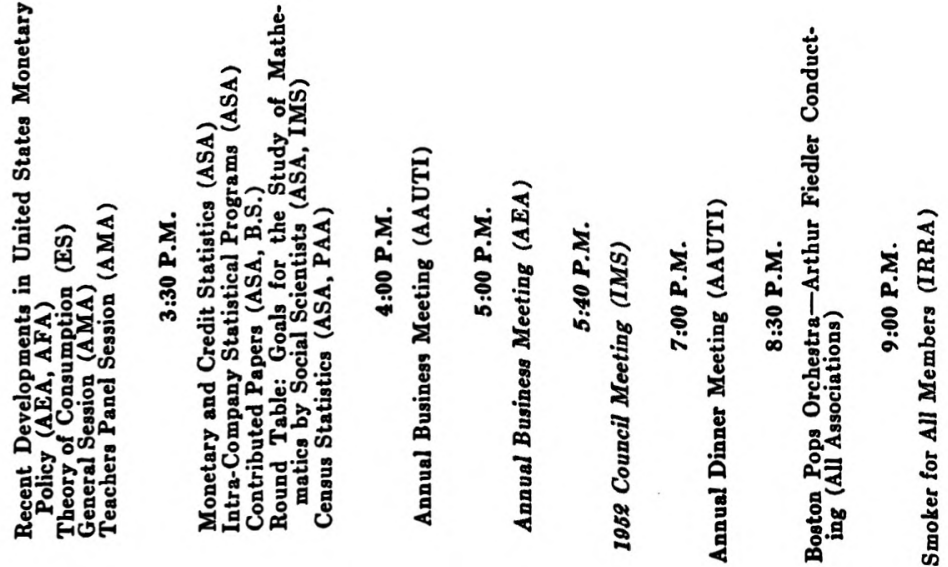

是
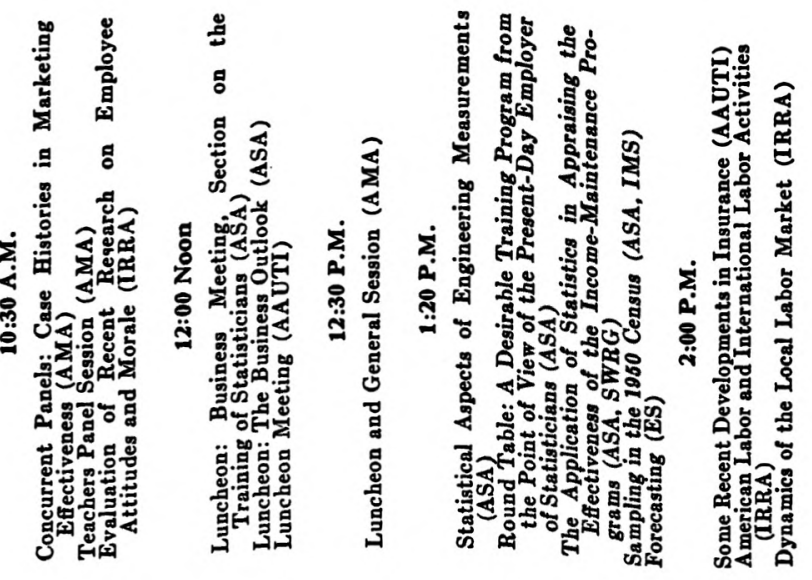

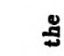

.

.

范通通

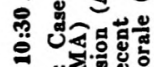

要通

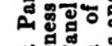

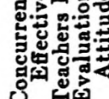

व
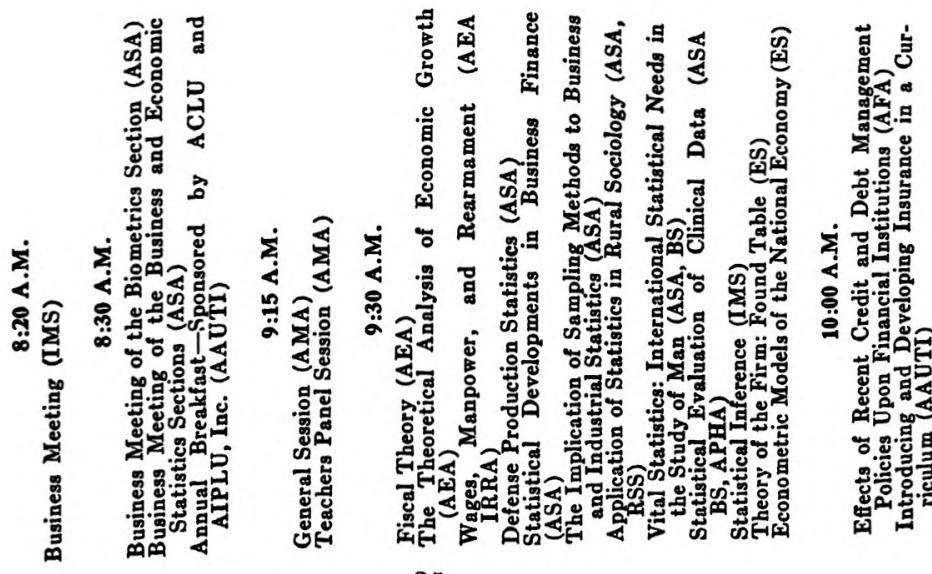
Among the recent

\section{OXFORD PUBLICATIONS}

on display in the foyer of the

Grand Ball Room

of the

Hotel Statler

will be the following titles

of interest to economists

\section{Ten Great Economists}

By Joseph A. Scbumpeter

320 pp. College Edition \$3.25

The Structure of the American Economy

By Wassily W. Leontief

288 pages $1951 \quad \$ 5.75$

The Social Framework of American Economy

By J. R. Hicks, and Albert G. Hart

280 pages $1945 \$ 3.50$

History of Economic Doctrines

By Eduard Heimann

272 pages $1945 \$ 3.75$

OXFOŔD UNIVERSITY PRESS

114 Fifth Avenue, New York

\section{SCHEDULE OF MEETINGS}

Friday, December 28, 1951

8:20-9:20 A.M. COPLEY-PLAZA

Business Meeting

Foyer

Institute of Mathematical Statistics

8:30-9:20 A.M. COPLEY-PLAZA

Business Meeting of the Biometrics Section American Statistical Association

Parlor C

Chairman: John W. Tukey, Princeton University

8:30-9:20 A.M. COPLEY-PLAZA Sheraton Room

Business Meeting of the Business and Economic Statistics Section

American Statistical Association

Chairman: Walter E. Hoadley, Ir., Armstrong Cork Company

8:30-9:30 A.M.

BRADFORD

Annual Breakfast-Sponsored by American Bradford Roof

College of Life Underwriters and American Institute for Property and Liability Underwriters, Inc.

American Association of University Teachers of Insurance

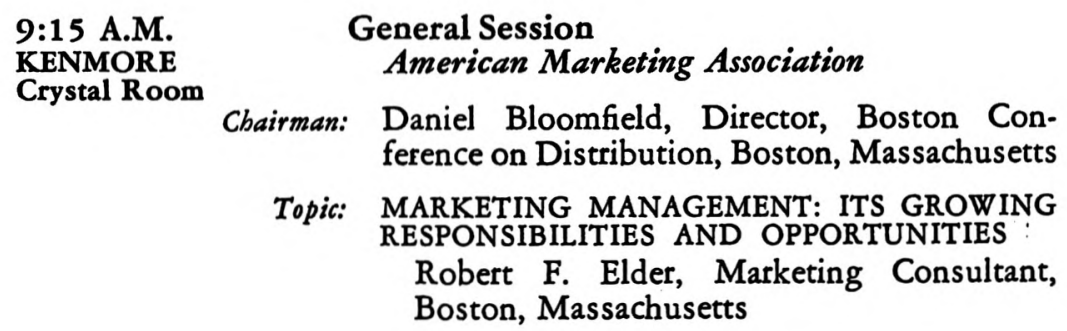

Chairman: Daniel Bloomfield, Director, Boston Conference on Distribution, Boston, Massachusetts

Topic: MARKETING MANAGEMENT: ITS GROWING RESPONSIBILITIES AND OPPORTUNITIES Robert F. Elder, Marketing Consultant, Boston, Massachusetts

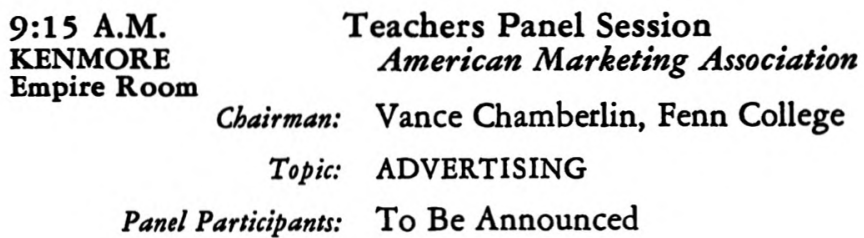


9:30 A.M. STATLER

Ballroom

\section{Fiscal Theory}

American Economic Association

Chairman: Roy Blough, Council of Economic Advisers

Papers: AN APPRAISAL OF CURRENT FISCAL THEORY Paul J. Strayer, Princeton University

THE ANTI-INFLATIONARY IMPLICATIONS OF ALTERNATIVE FORMS OF TAXATION

Richard B. Goode, International Monetary Fund

Discussion: Carl S. Shoup, Columbia University Harold M. Somers, University of Buffalo

9:30 A.M. STATLER Parlors A and B

The Theoretical Analysis of Economic Growth American Economic Association

Chairman: Harold A. Innis, University of Toronto

Papers: THE THEORETICAL ANALYSIS OF ECONOMIC GROWTH

Evsey D. Domar, Johns Hopkins University

ECONOMIC GROWTH - ECONOMETRIC MODELS IN RELATION TO THE SOCIAL SET. TING

David M. Wright, University of Virginia

Discussion: Thomas C. Schelling, Office of the Director of the Mutual Security Agency

Malcolm C. Urquhart, Queen's University

\section{9:30 A.M.}

STATLER

Georgian Room

Wages, Manpower, and Rearmament Joint Session: A.E.A., I.R.R.A.

Chairman: J. Douglas Brown, Princeton University

Papers: WAGE STABILIZATION

Clark Kerr, University of California at - Berkeley

PROBLEMS IN THE ALLOCATION OF MAN OWER

William Haber, University of Michigan

Discussion: Richard A. Lester, Princeton University Dale Yoder, University of Minnesota

Friday

9:30-11:30 A.M. COPLEY-PLAZA

Sheraton Room

Chairman: Frank Garfield, Board of Governors of The Federal Reserve System

Papers: CAPACITY REQUIREMENTS UNDER PARTIAL MOBILIZATION

Glenn McLaughlin, Defense Production Administration

PROBLEMS OF MEASUREMENT IN ALLOCATION OF SCARCE RESOURCES

Frederick Cone, Office of Defense Mobilization

Discussion: Walter E. Hoadley, Jr., Armstrong Cork Co. Ben Saurino, Sun Oil Company, Philadelphia, Pennsylvania

9:30-11:30 A.M. Statistical Developments in Business Finance COPLEY-PLAZA

Room 131

Chairman: John Lintner, Harvard Graduate School of Business Administration

Papers: A CRITICAI EVALUATION OF RECENT AD. DITIONS TO AND NEEDS FOR FINANCIAL STATISTICS COVERING BUSINESS OPERAGOVERNMENT ECONOMIST

Lawrence McHugh, U. S. Department of Commerce

A SECURITY ANALYST APPRAISES FINANCIAL STATISTICS

Lucien O. Hooper, W. E. Hutton \& Company, New York

Discussion: Eli Shapiro, University of Chicago

Miller Upton, Washington University, St. Louis, Missouri

9:30-11:30 A.M. COPLEY-PLAZA Oval Room

The Implication of Sampling Methods to Business and Industrial Statistics American Statistical Association

Chairman: Howard C. Grieves, U.S. Bureau of the Census

Papers: SAMPLING TECHNIQUES IN THE CURRENT BUSINESS PROGRAM

Max Bershad, Bureau of the Census 
MEASUREMENT OF COVERAGE IN THE 1948 CENSUS OF BUSINESS

Leon Pritzker, Bureau of the Census

THE ANNUAL SURVEY OF MANUFACTURES SAMPLE

Jack Ogus, Bureau of the Census

Discussion: Robert W. Burgess, Western Electric Company Howard L. Jones, Illinois Bell Telephone Company

\section{9:30-11:30 A.M. Application of Statistics in Rural Sociology} COPLEY.PLAZA Joint Session: A.S.A., R.S.S.

Copley Club

Chairman: Margaret Jarman Hagood, Bureau of Agricultural Economics, U. S. Department of Agriculture Papers: SOME CONSIDERATIONS IN THE USE OF THE MIGRATION

Jacob S. Siegel, U. S. Bureau of the Census C. Horace Hamilton, North Carolina State College of Agriculture

HOUSING FACILITIES AND EQUIPMENT OF HIRED FARM WORKERS AND THEIR EMPLOYERS

Barbara B. Reagan, Bureau of Human Nutrition and Home Economics, and Louis J. Ducoff, Bureau of Agricultural Economics,

U. S. Department of Agriculture

PROBLEMS IN QUANTITATIVE ANALYSIS OF EFFECT OF TRAINING PRACTICES OF THE PERSONAL ADJUSTMENTS OF RURAL CHIL

William H. Sewell, University of Wisconsin

Discussion: John Black, Harvard University Daniel O. Price, University of North Carolina Raymond F. Sletto, Ohio State University

\section{9:30-11:30 A.M. Vital Statistics: International Statistical Needs} COPLEY.PLAZA in the Study of Man

Parlor B

$$
\text { Joint Session: A.S.A., B.S. (ENAR) }
$$

Chairman: Paul M. Densen, University of Pittsburgh

Papers: INTERNATIONAL NEEDS FOR HEALTH STA. TISTICS

Knud Stowman, U. S. Public Health Service
EVOLVING MECHANISMS FOR THE PRODUCTION OF INTERNATIONAL HEALTH STATISTICS

Halbert L. Dunn, National Office of Vital Statistics

TRAINING PROBLEMS IN THE DEVELOPMENT OF INTERNATIONAL STATISTICS

Forrest Linder, United Nations

Discussion: Harry AJpert, Division of Statistical Standards, Bureau of the Budget

Paul M. Densen, University of Pittsburgh

9:30-11:30 A.M. Statistical Evaluation of Clinical Data COPLEY.PLAZA Parlor C

Joint Session: A.S.A., B.S. (ENAR), A.P.H.A. (S.S.)

Chairman: Jane Worcester, Harvard University

Papers: ESTIMATE OF EFFECTIVENESS OF CANCER THERAPY FROM MORTALITY RECORDS

Joseph Berkson, Mayo Clinic

DO PERSONS LOST TO LONG TERM OBSERVATION HAVE THE SAME EXPERIENCE AS PERSONS OBSERVED?

A. P. Iskrant, U. S. Public Health Service

THE ESTIMATION OF RATES FROM CLINICAL DATA

Jerome Cornfield, National Cancer Institute

Discussion: Sidney Cutler, National Cancer Institute

\section{9:30-11:30 A.M. Statistical Inference}

COPLEY-PLAZA

Institute of Matbematical Statistics

Foyer

Chairman: S. S. Wilks, Princeton University

Papers: THE CHI-SQUARE TEST OF GOODNESS OF

W. G. Cochran, Johns Hopkins University ANALYZING STRAIGHT LINE DATA

Forman S. Acton, National Bureau of Standards, Institute of Numerical Analysis

Discussion: Jerzy Neyman, University of California at Berkeley

W. J. Youden, National Bureau of Standards 
9:30 A.M. STATLER 4th Floor

Chairman: Herbert Simon, Carnegie Institute of Technology W. W. Cooper and A. Charnes, Carnegie Institute of Technology

Discussion: J. Bain, University of California at Berkeley

A. Bavelas, Massachusetts Institute of Technology

R. Dorman, University of California at Berkeley

G. Holden, Kenwood Mills

C. Kaysen, Harvard University

9:30 A.M. COPLEY-PLAZA

State Suite

Chairman: Tjalling C. Koopmans, Cowles Commission

Papers: AN ECONOMETRIC MODEL OF INTERINDUSTRY MATERIAL FLOWS

R. W. Shephard, Rand Corporation AGGREGATION IN MACRO-ECONOMIC MODELS

L. Hurwicz, University of Minnesota

Discussion: M. Hastay, National Bureau of Economic Research

K. May, Carleton College

10:00 A.M.

STATLER

Parlor C

(necent Credit and Debt Management Policies Upon Financial Institutions American Finance Association

$\underline{\text { Friday }}$

Paper: THEORY OF THE FIRM

Chairman: Roy L. Reierson, Bankers Trust Company

Papers: EFFECT OF CREDIT AND DEBT MANAGEMENT POLICIES UPON THE COMMERCIAL BANKS Norris O. Johnson, National City Bank

EFFECT OF CREDIT AND DEBT MANAGEMENT POLICIES UPON THE LIFE INSURANCE COMPANIES

- James J. O'Leary, Life Insurance Associa- tion of America

Discussion: George T. Conklin, Guardian Life Insurance Company

William E. Dunkman, University of Rochester Burton C. Hallowell, Wesleyan University

Roland I. Robinson, Northwestern University
10:00 A.M. BRADFORD Reception Room 5th Floor

\section{0:30 A.M. KENMORE}

Silver Room

Chairman

Panel Participants.

Introducing and Developing Insurance in a Curriculum

American Association of University Teachers of Insurance

Chairman: Davis W. Gregg, American College of Life Underwriters

Paper: INTRODUCING AND DEVELOPING IN. SURANCE IN A CURRICULUM Hampton H. Irwin, Wayne University

Discussion: William T. Beadles, Illinois Wesleyan Uni-

versity Hert C. Graebner, Butler University

Concurrent Panels: Case Histories in Marketing Effectiveness

American Marketing Association

DISTRIBUTION COSTS

Richard M. Clewett, Northwestern University, and National Chairman, A.M.A., Committee on Distribution Costs

FINDING PRACTICAL WAYS TO INCREASE DISTRIBUTION EFFICIENCY

Charles W. Smith, McKinsey \& Company, New York

NEW LIGHT ON COST PRINCIPLES IN A DRUG STORE

Orin E. Burley, University of Pennsylvania

RECENT CHANGES IN DISTRIBUTION COSTS Paul D. Converse, University of Illinois

Wedgewood Room

PRICING

Chairman: Milton P. Brown, Harvard Graduate School of Business Administration

Panel Participants: A NEW PRICING PRINCIPLE FOR JOB-SHOP PRODUCT PRICING

Richard L. Hapgood, Senior Consultant, The Eddy-Rucker-Nickels Company, Cambridge PRICING IN MAIL ORDER SELLING John A. Smith, John A. Smith \& Staff, Boston Third Speaker to be Announced. 
Friday

Crystal Room

\section{ADVERTISING EFFECTIVENESS}

Chairman: Vergil D. Reed, Vice President, J. Walter Thompson Company

Panel Participants: THE CASE FOR ORANGES

Julian L. Watkins, Creative Account Executive, J. Walter Thompson Company

BENDIX HOME APPLIANCES: COLLEGE CASE HISTORY PROGRAM

Frank S. Ryan, Director of Advertising and Sales Promotion, Bendix Home Appliances Division, Avco Manufacturing Corporation

WANTED: 480,000 WOMEN

Theodore S. Repplier, President, The Advertising Council, Inc.

Boston Room

ADVANCES IN MARKETING OF FOOD AND FIBRES AND THEIR PRODUCTS

Chairman: Harry C. Trelogan, U. S. Department of Agriculture

Panel Participants: MARKETING STUDIES IN AN AGRICULTURAI RESEARCH PROGRAM

Harry C. Trelogan, U. S. Department of Agriculture

PLANNING A NEW WHOLESALE PRODUCE MARKET FOR BOSTON

W. C. Crow, U. S. Department of Agriculture COORDINATING THE MARKETING OF FLORIDA CITRUS FRUIT George H. Goldsborough, U. S. Department of Agriculture

CONSUMER REACTIONS TO AGRICULTURAI PRODUCTS AT INDUSTRIAL AND HOUSEHOLD LEVELS

Mrs. Trienah Meyers, U. S. Department of Agriculture
10:30 A.M. KENMORE
Teachers Panel Session American Marketing Association
Chairman: Alfred L. Seelye, University of Texas
Topic: INDUSTRIAL MARKETING
Panel Participants: To Be Announced

\section{Friday}

$10: 30$ A.M SOMERSET Lauis XIV

Evaluation of Recent Research on Employee Attitudes and Morale

Industrial Relations Research Association

Chairman: Alva F. Kindall, William Filene's Sons Company

Papers: THE MEANING AND MEASUREMENT OF MORALE

Robert K. Burns, University of Chicago

THE RELATION OF MORALE TO PRODUC. TIVITY

Robert Kahn and Eugene H. Jacobson, Survey Research Center, University of Michigan

Discussion: Solomon Barkin, Textile Workers Union of America

Alex Bavelas, Massachusetts Institute of Technology

Andrew Kuhn, Stop \& Shop, Inc.

12:00 Noon Luncheon: Business Meeting, Section on the COPLEY-PLAZA Training of Statisticians

Room 133 American Statistical Association

Chairman: Rutledge Vining, University of Virginia

12:00-3:20 P.M. Luncheon: The Business Outlook COPLEY-PLAZA American Statistical Association Oval Room

Chairman: Sumner H. Slichter, Harvard University

Speakers: Garfield Cox, University of Chicago Murray Shields, Bank of the Manhattan Company

\begin{tabular}{|c|c|c|}
\hline $\begin{array}{l}12: 00 \text { Noon } \\
\text { BRADFORD } \\
\text { Oval Room }\end{array}$ & & $\begin{array}{l}\text { Luncheon Meeting } \\
\text { American Association of University Teachers of } \\
\text { Insurance }\end{array}$ \\
\hline \multirow[t]{3}{*}{$\begin{array}{l}\text { 12:30 P.M. } \\
\text { KENMORE } \\
\text { Crystal Room }\end{array}$} & & $\begin{array}{l}\text { Luncheon and General Session } \\
\text { American Marketing Association }\end{array}$ \\
\hline & Chairman: & $\begin{array}{l}\text { George H. Brown, Northwestern University, } \\
\text { and National President, American Marketing } \\
\text { Association }\end{array}$ \\
\hline & Subject: & $\begin{array}{l}\text { BUSINESS MEETING OF THE NATIONAL } \\
\text { ASSOCIATION }\end{array}$ \\
\hline
\end{tabular}


1:20-3:20 P.M. COPLEY-PLAZA Foyer

Statistical Aspects of Engineering Measurements

American Statistical Association

Chairman: William R. Pabst, Jr., Department of the Navy

Papers: ON INTERVALS OF THE FORM $\bar{x} \pm k s$

Frank Proschan, National Bureau of Standards

THE USE OF REFERENCE STANDARDS

John Tukey, Princeton University

Discussion: Charles A. Bicking, Department of the Army

Irving W. Burr, Purdue University

\section{1:20-3:20 P.M.} COPLEY.PLAZA

Parlor B

\section{Round Table: A Desirable Training Program from the Point of View of the Present-Day Employer of Statisticians} American Statistical Association

Cbairman: Charles A. Glover, American Telephone \& Telegraph Company, New York City

Speakers: Wroe Alderson, Alderson and Sessions, Philadelphia

William C. Flaherty, Chrysler Corporation, Detroit

Harold Guillikson, Educational Testing Service, Princeton, New Jersey

Paul S. Olmstead, Bell Telephone Laboratories, Murray Hill, New Jersey

Benjamin J. Tepping, U. S. Bureau of the Census

Discussion: Lester Frankel, Alfred Politz Research, Inc. William G. Madow, University of Illinois Samuel S. Wilks, Princeton University

1:20-3:20 P.M. COPLEY-PLAZA Parlor C
The Application of Statistics in Appraising the Effectiveness of the Income-Maintenance Programs Joint Session: A.S.A., S.W.R.G.

Chairman: Anne E. Geddes, Social Security Administration

Papers: KNOWLEDGE CONCERNING THE EFFECTIVENESS OF THE PROGRAMS

Jacob Fisher, Social Security Administration THE GAPS IN OUR KNOWLEDGE: RESOURCES John McCaslin, Kentucky State Department of Economics

PROBLEMS IN EVALUATING THE EFFECTIVE. NESS OF A PROGRAM IN MEETING ITS OBJECTIVES

Josephine Williams, University of Chicago

1:20-3:20 P.M. COPLEY-PLAZA
Sheraton Room

Chairman:

Papers:
Sampling in the 1950 Census

Joint Session: A.S.A., I.M.S.

Morris H. Hansen, Bureau of the Census

SAMPLING IN THE 1950 CENSUS OF POPULA. TION AND HOUSING

Joseph Steinberg and Joseph Waksberg, U. S. Bureau of the Census

I THE BASIC POPULATION AND HOUSING SAMPLES

II THE SAMPLE FOR PRELIMINARY TABULA. TIONS (with A. Mindlin)

III SAMPLING INSPECTION OF CLERICAL PROCESSING (with T. Jabine)

IV THE SURVEY OF RESIDENTIAL FINANCING (with N. Lieder)

$\checkmark$ MEASUREMENT OF BIASES AND VARIANCES (with H. Hess)

SAMPLING IN THE 1950 CENSUS OF AGRICULTURE

Harold Nisselson and Floyd Berger, U. S. Bureau of the Census

Discussion: Earl E. Houseman, Bureau of Agricultural Economics, U. S. Department of Agriculture Frederick F. Stephan, Princeton University

\section{1:20 P.M.}

COPLEY-PLA

Forecasting

Econometric Society

Chairman: W. Allen Wallis, University of Chicago

Papers: THE ECONOMETRIC APPROACH TO FORECASTING

L. Klein, University of Michigan

CANADIAN EXPERIENCE IN FORECASTING FROM ECONOMETRIC MODELS

T. M. Brown, Department of Trade and Commerce, Ottawa

SOME PRACTICAL RESULTS OF FORECASTING

H. Barger, Columbia University

Discussion: R. W. Adams, Standard Oil of New Jersey

V. L. Bassie, University of Illinois

P. Boschan, Econometric Institute 
2:00 P.M.

BRADFORD

Reception Room
5th Floor

Chairman: Harry J. Loman, University of Pennsylvania

Papers: THE IMPACT OF MULTIPLE LINE POWERS ON THE INSURANCE INDUSTRY

$\mathrm{H}$. Clay Johnson, Royal-Liverpool Insurance Group

THE IMPACT OF NEW DISABILITY COVER AGE ON THE LIFE INSURANCE COMPANIES John H. Miller, Monarch Life Insurance Company

2:00 P.M. SOMERSET Louis XIV Ballroom Chairman: Walter Galenson, University of California at

Papers: (Topics to be announced) Philip Delaney, American Federation of Labor Michael Ross, Congress of Industrial Organizations

Discussion: Daniel Horowitz, Department of State Philip Kaiser, Assistant Secretary of Labor

Robert Oliver, Economic Cooperation Administration

2:00 P.M. SOMERSE'T Princess

Chairman: E. J. Eberling, Tennessee Department of Employment Security, and Vanderbilt University

Papers: FINDINGS OF RECENT STUDIES

George P. Shultz, Massachusetts Institute of Technology

ADMINISTRATIVE APPLICATIONS

- Don H. Roney, California Department of - Employment

Discussion: E. C. Cain, Carbide and Carbon Chemical Co. William Haber, University of Michigan

Louis Levine, Bureau of Employment Security Ted F. Silvey, Congress of Industrial Organiza. tions

\section{Friday}

2:30 P.M.

STATLER

Parlors A and B

Chairman: Edward H. Chamberlin, Harvard University

Papers: A REHABILITATION OF PARTIAL ANALYSIS Melvin W. Reder, Stanford University DYNAMIC ASPECTS OF OLIGOPOLY PRICE THEORY

$$
\text { Carl Kaysen, Harvard University }
$$

Discussion: Gardner Ackley, Office of Price Stabilization Joe S. Bain, University of California

2:30 P.M. STATLER Ballroom

General Factors in Economic Growth in the United States

Joint Session: A.E.A., A.S.A.

Chairman: Arthur F. Burns, Columbia University and National Bureau of Economic Research

Papers: RELATION OF CAPITAL FORMATION TO NATIONAL PRODUCT

Simon Kuznets, University of Pennsylvania and National Bureau of Economic Research

SECULAR CHANGE IN INCOME DISTRIBUTION Geoffrey $H$. Moore, National Bureau of Economic Research

THE ROLE OF PRODUCTIVITY IN ECONOMIC GROWTH

Frederick C. Mills, Columbia University and National Bureau of Economic Research

Discussion: James S. Duesenberry, Harvard University Frank R. Garfield, Federal Reserve Board Raymond W. Goldsmith, Washington, D. C.

2:30 P.M. STATLER Georgian Room

Chairman: Alfred C. Neal, Federal Reserve Bank of Boston

Papers: INTEGRATING DEBT MANAGEMENT AND OPEN MARKET OPERATIONS

Robert V. Rosa, Federal Reserve Bank of New York

CONTROL OVER BANK PORTFOLIOS AS AN INSTRUMENT OF MONETARY CONTROL Lawrence W. Seltzer, Wayne University 


\section{A CHECK LIST OF IRWIN TEXTS IN ECONOMICS}

\section{BUSINESS ECONOMICS} Principles and Cases. Alt, Formerly, The Johns Hopkins
By. R. M. Alt, For
University, and W. C. Bradford, Northwestern University

WELFARE AND COMPETITION

The Economics of a Fully Employed Economy
By Tibor Scitovaly, Stanford University ECONOMICS OF LABOR RELATIONS By Frederic Meyers, University of Texas MONEY, INCOME, AND MONETARY POLICY

By E. S. Shaw, Stanford University INTERMEDIATE ECONOMIC ANALYSIS Revised Edition
By J. F. Due, University of Illinois COLLECTIVE BARGAINING Principles and Cases ${ }_{\text {By John T. Dunlop, Harvard Univernity }}$ MEASURES OF BUSINESS CHANGE A Baker Library Index QUALITY GONTROL AND INDUSTRIAL STATISTICS By A. J. Duncan, The Johns Hopkins Univeraity INVESTMENT ANALYSIS AND MANAGEMENT By L. V. Plum and J. H. Humphrey, Jr. FINANCIAL INSTITUTIONS By E. W. Boehmler (Editor), R. I. Robinson,
E. H. Gane, and L. C. Farwell, all of North-
western University

POLICY FORMULATION AND ADMINISTRATION

A Casebook of Top-Management Problems in Businos

THE REGULATION OF INDUSTRY

- By D. F. Pegrum, University of California at

RICHARD D. IRWIN, INC.

AN APPRAISAL OF SELECTIVE CREDIT CONTROLS

R. J. Saulnier, Barnard College, Columbia University, and National Bureau of Economic Research

Discussion: Howard R. Bowen, University of Illinois Lester V. Chandler, Princeton University Paul W. McCracken, University of Michigan

\section{2:30 P.M. STATLER} 4th Floor

Theory of Consumption Econometric Society

Chairmar: Dorothy S. Brady, U. S. Bureau of Labor Statistics

Papers: A SURVEY OF THE THEORY OF RATIONING J. Tobin, Yale University

SOME IMPLICATIONS OF EMPIRICAL RE. SEARCH FOR CONSUMPTION THEORY

H. S. Houthakker, Cambridge University PREDICTION IAND VARIOUS CONSUMPTION FUNCTIONS

T. E. Davis, Johns Hopkins University

Discussion: Elizabeth W. Gilboy, Harvard University I. Schweiger, Federal Reserve Board Eleanor M. Snyder, U. S. Bureau of Labor Statistics

2:30 P.M. KENMORE Crystal Room

Cbairman: Ross M. Cunningham, Massachusetts Institute of Technology

Subject: HOW MANAGEMENT USES MARKETING RESEARCH

Discussion: Shea Smith, III, Manager of Business Research, and Howard J. Heffernan, General Manager of Sales, Monsanto Chemical Company

D. E. Megathlin, Director of Market Research, and W. O. Forssell, Divisional Vice President, Kendall Mills

Frank W. Mansfield, Director of Sales Research, and Terry P. Cunningham, Director of Advertising and Sales Promotion, Sylvania Electric Products, Inc. 


\section{Well-recommended Texts of Recent Date}

\section{Mathematics of Finance}

Albert E. May, Assistant Director "Most textbooks on this subject have far too many formulas with the result that the student fails to understand underlying principles. A strong feature of this text is the careful development, with diagrams, of the procedures used and the limitation on the number of formus presented.

-K. G. Fuller, Teachers College of Connecticut

\section{Economics of Investment $\quad \begin{aligned} & \text { Jacob O. Kamm, Director, School of } \\ & \text { Commerce, Baldwin-Wallace College }\end{aligned}$} "This book should be especially useful for a course in investments not preceded by a course in corporation finance. Its simplicity and sound theory make it suitable for an elementary course, but the theory is illustrated and enriched by a practical background. Thus the book should be valuable to the practical investor as well as to the student. - H. G. Fraine, University of Wisconsin

\section{Elementary Economics}

Leland J. Gordon, Chairman, Dept. of Economics, Denison University

Teacher's Short-answer Questions . Student's Manual . Teacher's Manual and Key "I like the approach of Professor Gordon's Elementary Economics using day to day experience of the student who is also a consumer. The use of this text is bound to make the science of economics more interesting and understandable for the beginning student." -E. Eldridge Brewster, Kansas Wesleyan University

Economics for Consumers $\quad \begin{aligned} & \text { Leland J. Gordon, Chairman, Dept. } \\ & \text { of Economics, Denison University }\end{aligned}$ Second "Leland Gordon has produced the outstanding work in the field. Edition The second edition of his well-accepted Economics for Consumers is a thoroughy revised volume, which will undoubtedly take its place as the standard book on the subject."

-Colston E. Warne of Amherst College in the Survey Midmonthly (now Tho

\section{Public Finance}

William Withers, Associate Profes sor of Economics, Queens College

"Aside from its emphasis upon Keynesian doctrines, one of the most unusual features of this volume is its Introduction. This takes up one-fourth of the entire text and is composed mostly of what might be called a tax or financial history of the United States." - -Roy G. Blakey of the University of California at Los Angeles in the American Economic Review AMERICAN BOOK COMPANY
2:30 P.M.

KENMORE

Silver Room

\section{Topic}

Chairman:

Panel Participants

\section{WHAT IS AH}

George Company

WHAT IS WRONG WITH RETAIL EDUCATION? Arthur Einstein, Pennsylvania State College THE FUTURE FOR SCHOOLS AND DEPART. MENTS OF RETAILING

W. K. Dolva, Washington University

\section{3:30-5:30 P.M. COPLEY-PLAZA \\ Foyer}

Chairman

Papers:

Monetary and Credit Statistics

American Statistical Association

Carl E. Parry, Washington, D. C. FACTS NEEDED FOR MONETARY POLICY

Roland I. Robinson, Northwestern University

FACTS NEEDED FOR MONETARY POLICY

Earl Hicks, International Monetary Fund

Discussion: Henry C. Wallich, Yale University Richard Youngdahl, Board of Governors, Federal Reserve System

3:30-5:30 P.M. Intra-Company Statistical Programs COPLEY-PLAZA

Parlor C

Chairman: Robert W. Burgess, Western Electric Company

Papers: ANALYSIS AND FORECASTS OF COMPANY SALES

Edmund R. King, Eastman Kodak Company INVENTORY CONTROL IN DEPARTMENT STORES

Q. Forrest Walker, R. H. Macy and Company

MORTGAGE EXPERIENCE STUDIES

Eleanor S. Bagley, Mutual Life Insurance Company of New York

INTRA-COMPANY STATISTICS IN THE STAN DARD OIL COMPANY OF NEW JERSEY C. Ashley Wright, Standard Oil Company of New Jersey 
3:30-5:30 P.M. COPLEY-PLAZ Copley Club

Contributed Papers

Joint Session: A.S.A., B.S. (ENAR)

Cbairman: Horace W. Norton, University of Illinois

Papers: ESTIMATION OF THE T-YEAR SURVIVAL RATE FROM FOLLOW.UP STUDIES

Arthur S. Littell, Western Reserve University

WEIGHTING INVERSELY AS THE ESTIMATED

Sarah Porter Carroll and W. G. Cochran, Johns Hopkins University

AN APTITUDE TEST FOR PREDICTING SUCCESS IN STATISTICAL ACHIEVEMENT

D. F. Votaw, Sr., Southern Texas State Teachers College

3:30-5:30 P.M COPLEY-PLAZA Parlor B

Round Table: Goals for the Study of Mathematics by Social Scientists

Joint Session: A.S.A., I.M.S.

Chairman: William G. Madow, University of Illinois

Speakers: Paul F. Lazarsfeld, Columbia University Jacob Marschak, University of Chicago

Paul Samuelson, Massachusetts Institute of Technology

Frederick F. Stephan, Princeton University

Rutledge Vining, University of Virginia

Discussion: Members of the Committee on the Mathematical Training of Social Scientists

\section{3:30-5:30 P.M. COPLEY.PLAZA}

Sheraton Room

\section{Chairman: Roy V. Peel, Bureau of the Census}

Papers:" INTERNATIONAL COORDINATION OF LATIN

Calvert L. Dedrick, Bureau of the Census

CANADA'S 1951 CENSUS

O. A. Lemieux, Dominion Bureau of Statistics, Canada
CENSUS RESEARCH IN DATA COLLECTION TECHNIQUES

Lowell T. Galt, Bureau of the Census

Discussion: Forrest Linder, United Nations

Donald Riley, Division of Statistical Standards, Bureau of the Budget

4:00 P.M.

BRADFORD

Gov. Bradford

Annual Business Meeting

American Association of University Teachers of Insurance

Room

5:00 P.M.

STATLER

Parlors A and B

Annual Business Meeting American Economic Association

5:40 P.M.

COPLEY-PLAZA

Room 133

1952 Council Meeting

Institute of Matbematical Statistics

7:00 P.M.

Bradford Roof

\section{Annual Dinner Meeting}

American Association of University Teachers of Insurance

Speaker: Julian D. Anthony, President, The Columbian National Life Insurance Company

8:30 P.M.

STATLER

Ballroom

9:00 P.M.

SOMERSET

Louis XIV

Ballroom
Boston Pops Orchestra-Arthur Fiedler Conducting All Associations

Smoker for All Members Industrial Relations Researcb Association 


\section{NOR T O N}

announces

for spring publication

\section{Basic Statistics}

A Textbook with Special Reference

to Economics and Business

BY GEORGE SIMPSON and FRITZ KAFKA

Readings in Money and Banking

Edited by CHARLES R. WHITTLESEY

\section{The Theory of Economic Growth}

BY WALT W. ROSTOW

"Books That Live"

W. W. NORTON \& COMPANY, INC. 101 Fifth Avenue, New York 3, N. Y.

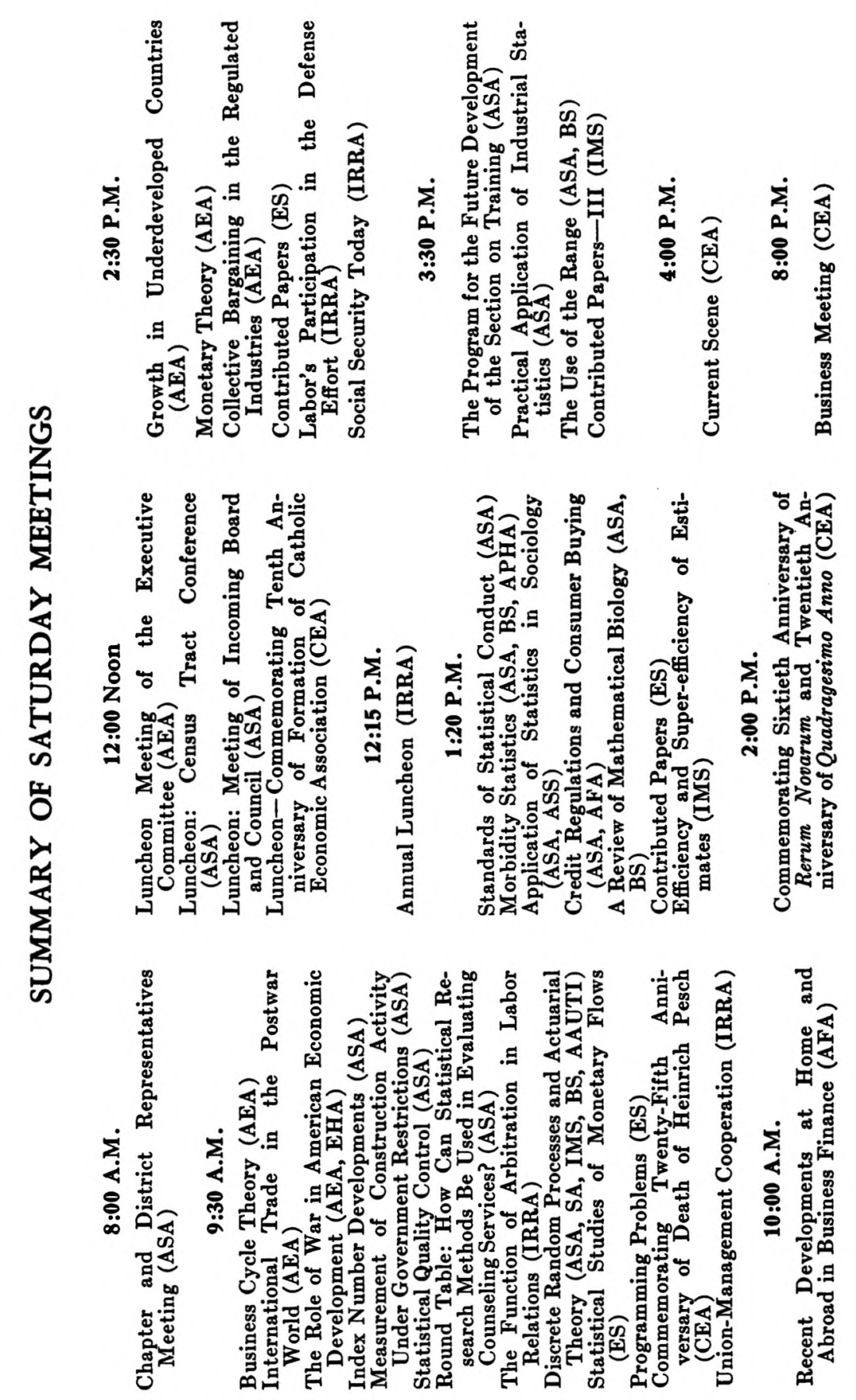

57 


\section{ADVANCE INFORMATION}

Fortbcoming WILEY Books

Kempthorne-THE DESIGN AND ANALYSIS OF EXPERIMENTS.* January 1952. Approx. 600 pages. Prob. $\$ 8.00$.

Tinter - ECONOMETRICS. March 1952. Approx. 330 pages. Prob. \$5.75.

Hald - STATISTICAL THEORY WITH ENGINEERING APPLICATIONS.* February 1952. Approx. 654 pages. Prob. $\$ 7.50$

Rao- ADVANCED STATISTICAL METHODS IN BIOMETRIC RESEARCH.* May 1952. Approx. 394 pages. Prob. \$7.50.

\section{Published in 1951}

Jaffe-Stewart - MANPOWER RESOURCES AND UTILIZATION, Principles of Working Force Analysis. 1951. 532 pages. \$6.50.

Mudgett - INDEX NUMBERS.* 1951. 135 pages. $\$ 3.00$.

Goode - THE CORPORATION INCOME TAX. 1951. 242 pages. $\$ 3.00$

Arrow-SOCIAL CHOICE AND INDIVIDUAL VALUES. Cowles Commission Monograph *12. 1951. 99 pages. $\$ 2.50$.

Waite-Trelogan - AGRICULTURAL MARKET PRICES, Second Edition. 1951. 440 pages. $\$ 5.25$.

Shultz - PRESSURES ON WAGE DECISIONS: A Case Study in the Shoe Industry. A Technology Press book, M.I.T. 1951. 142 pages. $\$ 3.00$.

Buros-STATISTICAL METHODOLOGY REVIEWS, 1941-1950. 1951. 457 double-column pages. $\$ 7.00$.

Koopmans - ACTIVITY ANALYSIS OF PRODUCTION AND ALLO. CATION. Cowles Commission Monograph 13. 1951. 404 pages. $\$ 4.50$

Morse-Kimball-METHODS OF OPERATIONS RESEARCH. A Technology Press book, M.I.T. 1951. 158 pages. $\$ 4.00$.

Nicholson - AIR TRANSPORTATION MANAGEMENT, Its Practices and Policies. 1951. 446 pages. \$6.50.

Larson-Gaumnitz - LIFE INSURANCE MATHEMATICS. 1951.184 pages. \$3.75.

*A Wiley Publication in Statistics, Walter E. Shewhart, Editor

Send for copies on approval

JOHN WILEY \& SONS, Inc. 440 Fourth Avenue, New York 16

\section{SCHEDULE OF MEETINGS}

Saturday, December 29, 1951 8:00-9:30 A.M
COPLEY-PLAZA Room 133

Chapter and District Representatives Meeting American Statistical Association

9:30 A.M

STATLER

Business Cycle Theory American Economic Association

Chairman: Moses Abramovitz, Stanford University

Papers: TOWARD A DYNAMIC THEORY OF THE CYCLE Alvin H. Hansen, Harvard University WAGES IN THE BUSINESS CYCLE Lloyd G. Reynolds, Yale University

Discussion: Robert A. Gordon, University of California Joseph Shister, University of Buffalo

9:30 A.M. International Trade in the Postwar World STATLER American Economic Association

Chairman: John B. Condliffe, University of California

Papers: METHODS OF ADJUSTMENT IN INTERNA. TIONAL PAYMENTS-THE LESSONS OF POST. WAR EXPERIENCE Emile Despres, Williams College, and C. P. Kindleberger, Massachusetts Institute of Technology

REGIONAL ORGANIZATION IN THE SPHERE OF TRADE AND PAYMENTS-WESTERN J. Marcus Fleming, Columbia University

Discussion: Albert O. Hirschman, Federal Reserve Board Robert Triffin, Yale University

9:30 A.M. STATLER Parlors $A$ and $B$

Chairma

Papers: WARTIME CHANGES IN THE MONEY SUPPLY IN THE UNITED STATES Milton Friedman, University of Chicago 
THE EFFECTS OF THE CIVIL WAR AND THE TWO WORID WARS ON AMERICAN TRANS ORTATION

John G. B. Hutchins, Cornell University

Discussion: Milton Heath, University of North Carolina C. R. Whittlesey, University of Pennsylvania
9:30-11:30 A.M. COPLEY-PLAZA

Cbairman: Geoffrey H. Moore, National Bureau of Economic Research RESERVE INDEX OF INDUSTRIAL PRODUC. TION

Lorman C. Trueblood and Arthur Broida, Board of Governors, Federal Reserve System

MINIMIZING ERRORS IN THE CONSTRUCTION AND USE OF PRICE INDEXES

Representative of the U. S. Bureau of Labor Statistics

Discussion: Barrie N. Davies, Statistical Office of the United Nations

Francis E. McIntyre, California Texas Oil Company, Ltd.

J. S. Stock, McCann-Erickson Company

9:30-11:30 A.M. Measurement of Construction Activity Under COPLEY-PLAZA Government Restrictions

Parlor B
Papers: PROGRESS IN THE REVISION OF THE FEDERAI

Chairman: Walter E. Hoadley, Jr., Armstrong Cork Company

Papers: NEW DEVELOPMENTS IN GOVERNMENT CONSTRUCTION STATISTICS

E. Everett Ashley, 3rd., U. S. Housing and Home Finance Agency

THE 1952 CONSTRUCTION OUTLOOK Clyde Shute, F. W. Dodge Corporation

Discussion: P. H. Raley, American Radiator and Standard Sanitary Corporation

- H. E. Riley, U. S. Bureau of Labor Statistics

9:30-11:30 A.M. Statistical Quality Control COPLEY-PLAZA

Foyer

Chairman: Ellis R. Ott, Rutgers University

9:30-11:30 A.M. Round Table: How Can Statistical Research COPLEY-PLAZA Methods Be Used in Evaluating Counseling Parlor C Services?

Joint Session: A.S.A., S.W.R.G.

Chairman: Edward E. Schwartz, U. S. Children's Bureau

Speakers: Leonard S. Kogan, Community Service Society of New York

Eli S. Marks, U. S. Bureau of the Census

9:30 A.M. The Function of Arbitration in Labor RelaSOMERSET tions

Louis XIV

Ballroom

Industrial Relations Research Association

Cbairman: George W. Taylor, University of Pennsylvania

Papers: COLLECTIVE BARGAINING, FREE ENTERPRISE, AND THE ARBITRATION PROCESS

I. L. Sharfman, University of Michigan

ARBITRATION-WHOSE RESPONSIBILITY? David L. Cole

Discussion: Dexter M. Keezer, McGraw-Hill Publishing Company

Clark Kerr, University of California at Berkeley

Benjamin M. Selekman, Harvard University

9:30-11:30 A.M. COPLEY-PLAZA Oval Room

Chairman
surance Company
Paper: DISCRETE RANDOM PROCESSES-THE PROB- ABILITY BASIS OF MORTALITY THEORY H. L. Seal, Morss \& Seal, N. Y.

Discussion: $\quad$ H. W. Alexander, Adrian College

T. N. E. Greville, National Office of Vital Statistics, U. S. Public Health Service

John E. Walsh, U. S. Naval Ordnance Test Station 


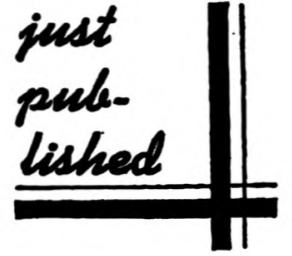

THE ECONOMICS of ARMAMENT INFLATION

Jules Backman, New York Univ. 234 pp. $\$ 1.75$

Provides an inexpensive means of adequately treating in the principles course an area substantially neglected in most current texts. contents: Nature of Armament Inflation : Armament Inflation and Fiscal Policy - Credit Controls and Monetary Policy - Direct Price Controls - Subsidy Payments. Consumer Rationing - Wage Stabilization - Defense Production Act with Amendments, 1951.

\section{WAR and DEFENSE ECONOMICS Jules Backman and Others} prob. 600 pp., $\$ 5.00$

A detailed analysis of the problems of an economy which must pay a major concern to defense and armament. It covers today's moderate armament economy program as well as the program in all-out war. It integrates theory and practice and draws heavily upon experiences in World Wars I and II and the first year of the Korean War.

\section{ECONOMIC SYSTEMS IN ACTION:} US, USSR, UK

Alfred R. Oxenfeldt, City College of New York prob. 192 pp., $\$ 1.50$

A very up-to-date and complete book describing the workings of three present day economic systems. The discussion is oriented around the manner in which each deals with certain specific and fundamental economic problems.

\section{LAW in its APPLICATION to BUSINESS, Revised Ed. William $\mathrm{H}$. Schrampfer, Iowa State} prob. 1120 pp., $\$ 6.50$

In this new edition, stress has been placed upon the preventive aspects of law: Much of the text material has been rewritten and expanded, the number of illustrations has been greatly increased and modern cases have been introduced into the problem material.

\section{RINEHART \& CO. $\begin{gathered}232 \text { madison ave. } \\ \text { new york, } 16, \text { n.y. }\end{gathered}$}

jace. 15

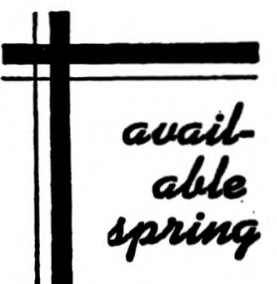

9:30 A.M. STATLER 4th Floor

\section{9:30 A.M. Programming Problems \\ COPLEY-PLAZA Econometric Society}

Chairman: C. B. Tompkins, George Washington University

Papers: SOME ASPECTS OF INVENTORY CONTROL J. Marschak, Cowles Commission ASPECTS OF .TECHNOLOGY AND ORGANI. ZATION

D. Rosenblatt, Carnegie Institute of Technology

Discussion: A. Bergson, Columbia University M. Flood, RAND Corporation
9:30 A.M. STATLER Parlor C
Commemorating Twenty-Fifth Anniversary of Death of Heinrich Pesch Catholic Economic Association

Chairman: Rev. W. Seavey Joyce, S. J., Boston College

Topic: ECONOMIC MEANING OF SOLIDARISM: PRE. NOTES TO VOCATIONAL GROUPING OF
ECONOMIC SOCIETY

Rev. Richard E. Mulcahy, S. J., University of San Francisco

Discussion: Franz H. Mueller, College of St. Thomas Sr. M. Thomasine, O. P., Rosary College 
9:30 A.M. SOMERSET Princess Ballroom

Chairman: Clinton Golden, Graduate School of Business Administration, Harvard University

Papers: SOME EXPERIENCES WITH A UNION-MANAGEMENT COOPERATION PLAN

Robert C. Tait, Stromberg-Carlson Company

LOCAL UNION EXPERIENCE WITH A CO OPERATION PLAN

Frederick G. Lesieur, LaPointe Machine Tool Company

Discussion: Neil W. Chamberlain, Yale University

W. R. Dymond, Department of Labour, Ottawa

William Gomberg, International Ladies' Garment Workers Union

\section{0:00 A.M. Recent Developments at Home and Abroad in \\ JOHN HANCOCK Business Finance}

BUILDING

American Finance Association

Chairman: Charles C. Abbott, Harvard University

Papers: DEFERRED DEPRECIATION - A CANADIAN ANTI-INFLATIONARY MEASURE

Mitchell W. Sharp, Associate Deputy Minister of the Department of Trade and Commerce

FINANCING BUSINESS EXPANSION SINCE KOREA

Robert P. Ulin, McGraw-Hill Publishing Company

INTERNATIONAL BUSINESS INVESTMENT: GOVERNMENTAL AND PRIVATE

Philip D. Bradley

Discussion: H. Frederick Hagemann, Jr., Rockland-Atlas National Bank of Boston

Frederick S. Morton, Davidson College

12:00 Noon STATLER Parlor F
Luncheon Meeting of the Executive Committee

American Economic Association

\section{$\underline{\text { Saturday }}$}

12:00-5:00 P.M. Luncheon: Census Tract Conference COPLEY-PLAZA American Statistical Association

Chairman: Howard Whipple Green, Cleveland Health Council

Papers: GREETINGS FROM THE BUREAU OF THE CENSUS

Roy V. Peel, Bureau of the Census

PUBLICATION SCHEDULE FOR THE SEVENTEENTH DECENNIAL CENSUS

Conrad Taeuber, Bureau of the Census

THE CANADIAN TRACT PROGRAM

O. A. Lemieux, Dominion Bureau of Statistics, Canada

Round Table Discussion: PUTTING CENSUS TRACTS TO WORK

BY CITY PLANNERS

Harlin G. Loomer, Philadelphia City Planning Association

BY HOUSING AGENCIES

Frank A. Mucha, Federal Housing Administration, New York City

BY VITAL STATISTICIANS

Rachel M. Jenss, Erie County Health Department, New York

BY SOCIAL AGENCIES

Dorothy W. Myers, United Community Services of Metropolitan Boston

BY RETAILERS

Donald R. G. Cowan, University of Michigan

BY MANUFACTURERS

W. Carl Masche, Browne \& Bigelow, St. Paul

BY BUSINESS

Irving M. Plant, Consolidated Edison Company of New York, Inc.

12:00 Noon

COPLEY-PLAZA

Room 133
Luncheon: Meeting of Incoming Board and Council.

American Statistical Association 
12:00 Noon STATLER Parlor C

Luncheon-Commemorating Tenth Anniversary of Formation of Catholic Economic Association

Catbolic Economic Association

Chairman: Josef Solterer, Georgetown University

Guest: His Excellency, The Most Reverend Richard J. Cushing, D.D., Archbishop of Boston

Topic: THE APPLICATION OF ECONOMIC SCIENCE NORMS AND VALUE JUDGMENTS

John H. Sheehan, University of Notre Dame, President of the Catholic Economic Association 12:15 P.M. Louis XIV Ballroom

\section{Annual Luncheon \\ Industrial Relations Research Association}

Speaker: President William M. Leiserson

\section{1:20-3:20 P.M. COPLEY-PLAZA} Parlor B

\section{Standards of Statistical Conduct} American Statistical Association

Chairman: Martin R. Gainsbrugh, National Industrial Conference Board

Papers: SIMPLIFICATION WITHOUT DECEPTION Andrew T. Court, General Motors Corporation

STATISTICAL STANDARDS AND THE CENSUS Morris H. Hansen, U. S. Bureau of the Census

THE STATISTICIAN AND HIS CONSCIENCE Theodore H. Brown, Harvard Graduate School of Business Administration

Discussion: W. W. K. Freeman, Mutual Boiler and Machinery Insurance Company

Clarence D. Long, Johns Hopkins University

J. E. Morton, Bureau of Mines, U. S. Department of Interior

\section{1:20-3:20 P.M. COPLEY-PLAZA} Copley Club

\section{Chairman:}

Papers:
Morbidity Statistics A.P.H.A. (S.S.)

Robert B. Reed, Harvard University

EVALUATION OF SELECTIVE SERVICE DEFECT STATISTICS

Bernard D. Karpinos, Department of the Army

FACTORS AFFECTING DISABILITY CLAIM AND TERMINATION RATES

Barkev S. Sanders, Social Security Administration

HOSPITAL RECORDS AS A SOURCE OF MORBIDITY STATISTICS

Marta Fraenkel, New York City Department of Hospitals

Discussion: Clifford A. Bachrach, Johns Hopkins School of Hygiene and Public Health

William M. Haenszel, Connecticut Department of Health

Morton Robins, Veterans Administration

1:20-3:20 P.M. Application of Statistics in Sociology

COPLEY-PLAZA Joint Session: A.S.A., A.S.S.

Boyer

Cbairman: Frank Lorimer, The American University

Papers: USE OF MARGIN-PUNCHED CARDS IN SCAL. ING SOCIAL DATA

Daniel O. Price, University of North Carolina PURPOSIVE SAMPLING IN A STUDY OF COMPURPOSIVE SAMPLING IN A STUDY OFS TO ATOMIC ENERGY

Charles A. Metzner, University of Michigan APPLICATION OF STATISTICS IN SOCIOLOGY Samuel A. Stouffer, Harvard University

Discussion: Robert T. Bower, The American University Dorothy S. Thomas, University of Pennsylvania

1:20-3:20 P.M. Credit Regulations and Consumer Buying COPLEY.PLAZA

Sheraton Room Joint Session: A.S.A., A.F.A.

Chairman: Ernst A. Dauer, Household Finance Corporation 

Papers: A CRITICAL EVALUATION OF AVAILABLE

Duncan Holthausen, Union City, New Jersey MEASURING THE IMPACT OF CONSUMER CREDIT CONTROLS ON SPENDING

Clarke L. Fauver and Ralph A. Young, Board of Governors of the Federal Reserve System

Discussion: Reavis Cox, University of Pennsylvania Avram Kisselgoff, Bank of New York and Fifth Avenue Bank

Wallace P. Mors, Western Reserve University Thomas W. Rogers, American Finance Conference

\section{1:20-3:20 P.M. COPLEY.PLAZA \\ A Review of Mathematical Biology Joint Session: A.S.A., B.S. (ENAR)} Room 131

Chairman: John Tukey, Princeton University

Papers: THE MATHEMATICAL BIOLOGY OF ORGANIC FORM

N. Rashevsky, University of Chicago THE THEORY OF THE CENTRAL NERVOUS SYSTEM

$$
\text { A. Rapoport, University of Chicago }
$$

EXCITATION AND THRESHOLD PHENOMENA IN IRRITABLE TISSUE

G. Karreman, University of Chicago

BIOPHYSICS OF CELL DIVISION

A. Shimbel, University of Chicago

\section{1:20 P.M.} COPLEY-PLAZA

\section{Contributed Papers} Econometric Society

Chairman: Robert Solow, Massachusetts Institute of Technology

Papers: THE INFLUENCE OF INTEREST RATES ON - TIME-SERIES OF PRICE

H. T. Davis, Northwestern University

THE INDEX NUMBER VECTOR AS A PROJEC TION OF THE GENERAL CONSTELLATION

P. Boschan, Econometric Institute

Discussion: General Discussion from the Floor

\section{1:20-3:20 P.M.} COPLEY-PLAZ State Suite

Chairman:

Papers: ON THE PROBLEM OF ASYMPTOTIC EFFIENCY OF ESTIMATES

Jerzy Neyman, University of California at Berkeley

LOCAL SUPER-EFFICIENCY

J. L. Hodges, University of Chicago

SETS OF PARAMETER POINTS AT WHICH ASYMPTOTIC SUPER-EFFICIENCY IS POSSIBLE

Lucien Le Cam, University of California at Berkeley RELATIVE PRECISION OF LEAST SQUARES OF REGRESSION COEFFICIENTS

Joseph Berkson, Mayo Clinic

Discussion: Agnes Berger, New York University

2:00 P.M. STATLER Parlor C
Commemorating Sixtieth Anniversary of Rerum Quadragesimo Anno

Catbolic Economic Association

Chairman: Sr. M. Alexine Beatty, S.S.J., Regis College

Topic: ECONOMIC RESEARCH AND THE SOCIAI ENCYCLICALS: PROGRESS AND POVERTY

Rev. John F. Cronin, S. S., Catholic University of America and Social Action Department of the National Catholic Welfare Conference

Discussion: Arthur F. Burns, Columbia University and National Bureau of Economic Research versity and National Bureau of Economic Research

Rev. Joseph M. Becker, S. J., Saint Louis University and Institute of Social Sciences 
2:30 P.M. STATLER Ballroom

\section{Growth in Underdeveloped Countries} American Economic Association

Chairman: Paul N. Rosenstein-Rodan, International Bank for Reconstruction and Development

Papers: SOME INTERNATIONAL ASPECTS OF THE PROBLEM OF ECONOMIC DEVELOPMENT

Ragnar Nurkse, Columbia University

THE FISCAL AND MONETARY IMPLEMENTATION OF DEVELOPMENT PROGRAMS

John H. Adler, International Bank for Reconstruction and Development

Discussion: Horst Mendershausen, Federal Reserve Bank of New York

Hans P. Neisser, New School for Social Research

H. W. Singer, United Nations

\section{2:30 P.M}

STATLER

Georgian Room

\section{Monetary Theory}

American Economic Association

Chairman: James W. Angell, Columbia University

Papers: INTEREST RATES, LIQUID ASSETS, AND SPEND. ING DECISIONS

James Tobin, Yale University

WARTIME MONETARY EVENTS AND MONETARY THEORY

Roland N. McKean, Vanderbilt University

Discussion: Edward S. Shaw, Stanford University Henry C. Wallich, Yale University

Collective Bargaining in the Regulated InParlor A

dustries

American Economic Association

Chairman: C. Emery Troxel, Wayne University

Papers: INTERDEPENDENCE OF WAGE AND PRICE DETERMINATION IN THE REGULATED IN. DUSTRIES

Eli W. Clemens, University of Maryland
THE REGULATORY AGENCY AND INDUSRIAL RELATIONS: THE AIRLINES CASE Mark Kahn, Wayne University

Discussion: Robert W. Harbeson, University of Illinois William N. Leonard, Pennsylvania State College

2:30 P.M. STATLER 4th Floor

\section{Contributed Papers}

Econometric Society

Chairman: Nicholas Georgescu-Roegen, Vanderbilt University

Papers: PROBLEMS OF SOCIAL SECURITY FROM AN ECONOMETRIC POINT OF VIEW

E. Schoenbaum, Mexican Institute of Social Security

INTERNATIONAL AGREEMENTS AND THE THEORY OF COMMITTEE DECISIONS

D. Black, University of Toronto

THE MECHANISM OF INTERNATIONAL AD. JUSTMENT

S. S. Alexander, International Monetary Fund

Discussion: General Discussion from the Floor

2:30 P.M. SOMERSET Louis XIV Ballroom

Chairman: Edward L. Cushman, Wayne University

Papers: WHAT DOES LABOR PARTICIPATION MEAN? H. H. Bookbinder, National Production Authority

THE PROBLEMS FOR THE LABOR MOVEMENT IN LABOR PARTICIPATION

George Brooks, International Brotherhood of Pulp, Sulphite and Paper Mills Workers

Discussion: Peter Henle, American Federation of Labor Richard Lester, Princeton University David Truman, Columbia University Murray Weisz, U. S. Bureau of Labor Statistics 


\section{Send for Examination Copies of these Important Textbooks . . . .}

Economics of Business Enterprise

GEORGE J. CADY, University of Rodlends. 452 pages.

\section{Corporate Finance and Regulation} CHELCIE C. BOSLAND, Brown University. 529 pages.

The Income of Society

ELIZABETH E. HOYT, Iowa State Colloge. 753 pages. $\$ 4.50$

\section{The International Economy}

JOFn P. YOUNG, Adviser, Office of Financial and Development
Policy. Dept. of Stato. Third Edition. 813 pages.

\section{Money, Credit and Banking}

RAY B. WESTERFIELD, Yalo University. Rovised Edition. ${ }^{1096} \$ 5.50$
pagos.

\section{Price Economics}

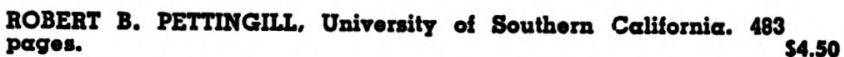

\section{Principles of Urban Real Estate}

ARTHUR M. WEMMER, Indiand University' and HOMER HOYT.

Homer Hoyt Associates, Consulting Urbern Leend Economists

vised Edition. 512 pages.

Economics of Income and Consumption

HELEN G. CANOYER and ROLAND S. VAILE, both of the Uni-
versity of Minnesota. 386 pages.

100 Short Problems in Corporation

\section{Finance}

HERBERT E. DOUGALI, Stanford Oniversity and HAROLD W.
TORGERSON, Northwestern University. Third Edition.

\section{The Stock Market}

GEORGE L. LEFFLER, The Pennsylvania State Colloge. 580 pages. $\$ 6.00$

\section{Personal Finance}

ELVIN F. DONALDSON, The Ohio State University. 499 pages. $\$ 4.50$

\section{Agenda for Progressive Taxation}

WILLIAM VICKREY, Columbie University, formerly tax consultant
to the obvernor of Puerto Rico. 496 pages.

THE RONALD PRESS COMPANY

15 East 26th Street, New York 10

Saturday

\section{2:30 P.M SOMERSET Princess
Ballroom}

Chairman: E. Wight Bakke, Yale University

Papers: APPROACHES TO OLD AGE SECURITY: GREAT BRITAIN AND SWEDEN

Helen F. Hohman, University of Chicago

SOCIAL SECURITY IN A PERIOD OF FULL EMPLOYMENT

Eveline M. Burns, Columbia University

Discussion: Floyd A. Bond, Pomona College

John W. McConnell, Cornell University

Glenn W. Miller, Ohio State University

H. M. Somers, Haverford College

3:30-5:30 P.M COPLEY.PLAZA

Sheraton Room

Chairman: George E. Nicholson, University of North Carolina

Discussion: Howard L. Jones, Illinois Bell Telephone Company William G. Madow, University of Illinois A. M. Mood, The RAND Corporation H. V. Roberts, University of Chicago Helen Walker, Columbia University

3:30-5:30 P.M. COPLEY-PLAZA

Parlor B

Cbairman: Paul Olmstead, Bell Telephone Laboratory, Murray Hill, New Jersey

Papers: ELECTRICAL ENGINEERING APPLICATION A. V. Feigenbaum, General Electric Company INTERFERENCE FAILURES IN SUB-ASSEMBLIES Arthur Bender, Delco-Remy Division, General Motors

FAILURES RELATING TO MEASUREMENT RELIABILITY

Thomas A. Budne, A. R. Squibb \& Sons 
3:30-5:30 P.M. COPLEY-PLAZA

Foye

The Use of the Range

Joint Session: A.S.A., B.S. (ENAR)

Chairman: Lila Knudsen Randolph

Papers: APPLICATIONS OF THE NON-CENTRAL "T" STATISTIC BASED ON THE AVERAGE RANGE Lincoln E. Moses and George J. Resnikoff, Stanford University

ANOTHER VIEWPOINT ON THE EFFICIENCY OF THE RANGE IN LARGE SAMPLES

Frederick Mosteller, Harvard University, and Joseph Berkson, Mayo Clinic

PROCESSING DATA FOR OUTLIERS AND THE EFFECT ON ESTIMATES OF LOCATION AND SCALE

W. J. Dixon, University of Oregon

TESTING A STRAGGLER MEAN IN A TWO-WAY CLASSIFICATION USING THE RANGE

Jack Moshman, Oak Ridge National Laboratory

Discussion: Joseph F. Daly, U. S. Bureau of the Census William R. Pabst, Jr., Department of the Navy

\section{3:30-5:20 P.M.} COPLEY-PLAZA

Contributed Papers-III

Institute of Matbematical Statistics

Chairman: E. B. Mode, Boston University

Papers: SUFFICIENT STATISTICS AND SELECTION DEPENDING ON THE PARAMETER

D. A. S. Fraser, University of Toronto

ON A PROBLEM SUGGESTED BY BLACKWELI (PRELIMINARY REPORT)

- Charles Stein, University of Chicago

ON A CLASS OF INFINITELY DIVISIBLE DISTRIBUTIONS

Gopinath Kallianpur, University of California at Berkeley and Herbert Robbins, University of North Carolina at Chapel Hill.

ON SETS OF PARAMETER POINTS WHERE IT IS POSSIBLE TO ACHIEVE SUPEREFFICI. ENCY OF ESTIMATES

Lucien LeCam, University of California at Berkeley

ON ESTIMATING PROB. $(\mathrm{Y}>\mathrm{X})$ FOR IN DEPENDENT X, Y

Z. W. Birnbaum, University of Washington and Stanford University.

ALMOST SURE ESTIMABILITY OF LINEAR STRUCTURES IN n-DIMENSIONS

T. A. Jeeves, University of California at Berkeley.

COMPLETENESS OF THE CLASS OF ADMISSIBLE DECISION PROCEDURES

Herman Rubin, Stanford University

MOMENT PROBLEM SOLUTIONS WITH CONTINUOUS DERIVATIVES

Lionel Weiss, University of Virginia

SIGNIFICANCE CONSISTENCY OF THE BASIC NEYMAN-PEARSON TEST. (BY TITLE).

L. M. Court, American Power Jet Company, New York, N. Y

4:00 P.M.

STATLER

Parlor C

STATLER

\author{
Current Scene \\ Catbolic Economic Association \\ Chairman: Rev. Charles B. Quirk, O. P., Providence College \\ Topic: PROBLEM OF A DEFENSE ECONOMY: PRES. \\ SURE GROUPS VS. SOCIAL JUSTICE \\ Speaker: Joseph C. O'Mahoney, United States Senator, \\ Wyoming \\ Discussion: Walter Froehlich, Marquette University \\ Rev. Jerome L. Toner, O. S. B., Saint Martin's \\ College
}

\section{Business Meeting}

Catholic Economic Association 


\section{and Forthcoming Books}

\section{Selected Books of particular inferest to:}

\section{American Economic Association \\ American Finance Association \\ American Marketing Associatio \\ American Statistical Association}

\section{ECONOMICS}

Umbreit, Hunt, and Kinter

FUNDAMENTALS OF ECONOMICS, 2/e Ready in March

Mikesell

UNITED STATES ECONOMIC POLICY AND INTER-

NATIONAL RELATIONS

\section{Goldenweiser}

AMERICAN MONETARY POLICY

391 pages, $\$ 4.50$

AN INTRODUCTION TO AGRICULTURAL ECONOMICS

Katona

414 pages, $\$ 5.00$

PSYCHOLOGICAL ANALYSIS OF ECONOMIC BEHAVIOR

Mueller

MONEY AND BANKING

347 pages, $\$ 5.00$

807 pages, $\$ 6.00$

Samuelson

ECONOMICS, 2/e

762 pages, $\$ 5.00$

Wright

CAPITALISM

246 pages, $\$ 3.25$

Scitovsky, Shaw, and Tarshis

MOBILIZING RESOURCES FOR WAR

284 pages, $\$ 4.50$

\section{FINANCE}

Dice and Eiteman

THE STOEK MARKET, 3/e

Graham and Dodd

SECURITY ANALYSIS, $3 / \mathrm{e}$

Ready in January

770 pages, (text ed.) $\$ 6.00$

McGRAW-HILL BOOK COMPANY, INC.

Studenski and Krooss

FINANCIAL HISTORY OF THE UNITED STATES

Ready in January

THE MANAGEMENT OF BANK FUNDS 425 pages, $\$ 5.50$

MARKETING

Thomsen

AGRICULTURAL MARKETING 481 pages, $\$ 6.00$

Brennen

ADVERTISING MEDIA

410 pages, $\$ 6.00$

Seehafer and Laemmar

SUCCESSFUL RADIO AND TELEVISION ADVERTISING

574 pages, $\$ 6.50$

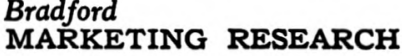

379 pages, $\$ 5.00$

Agnew and Houghton

MARKETING POLICIES, 2/e 590 pages, $\$ 6.50$

Lorie and Roberts

RCH

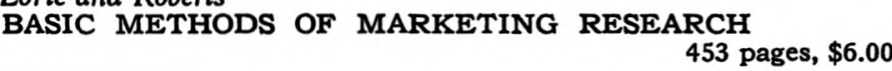

\section{STATISTICS}

Waugh

ELEMENTS OF STATISTICAL METHOD, 3/e

Ready in Apri

SAMPLING INSPECTION BY VARIABLES Ready in January

Paden and Lindquist

STATISTICS FOR ECONOMICS AND BUSINESS

Riggleman and Frisbee

270 pages, $\$ 3.75$

BUSINESS STATISTICS, $3 / \mathrm{e}$

818 pages, $\$ 5.50$

Munroe

THE THEORY OF PROBABILITY

213 pages, $\$ 4.50$

Visit our booth to examine other texts and reference books.

Orders may be left at any time during the meetings.

330 West 42nd Street, New York 18, N.Y. 
INDEX OF PARTICIPANTS

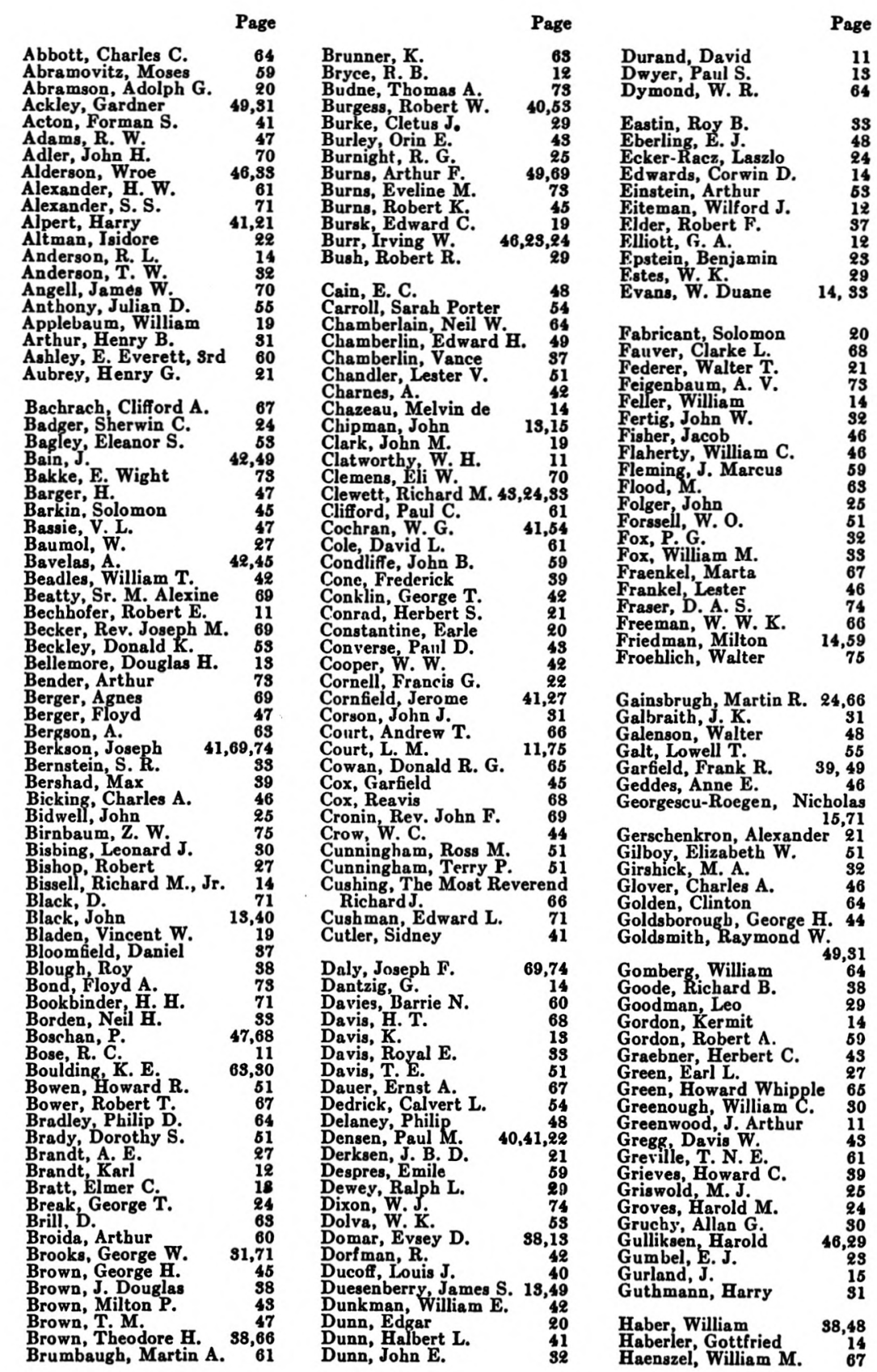

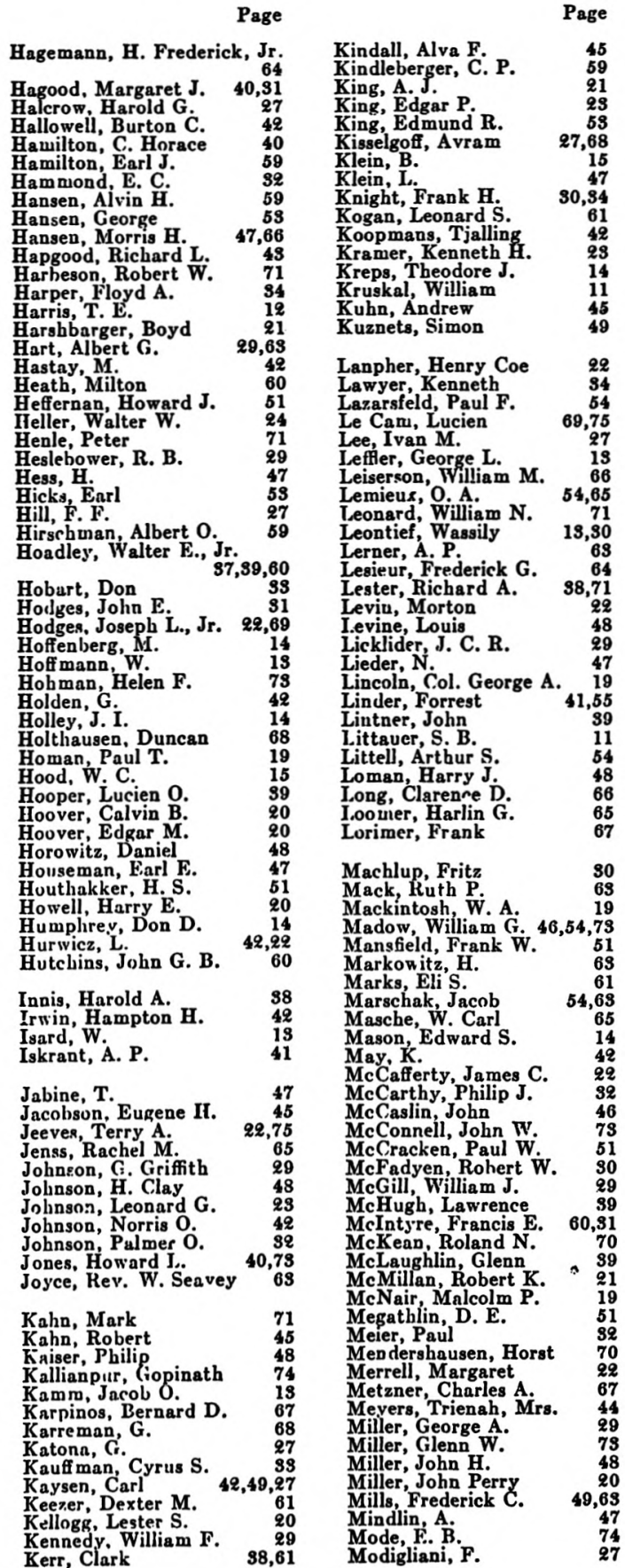

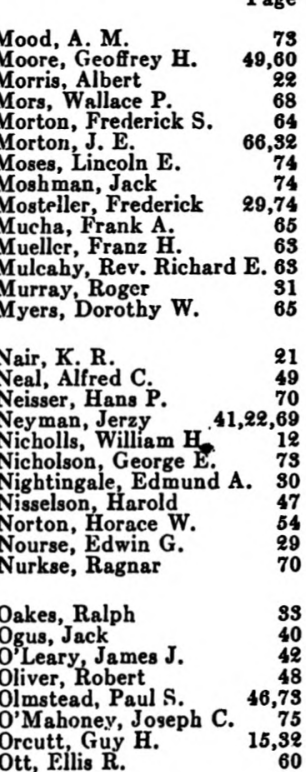

Pabst, William R., Jr. 46,74

Parsons, Kenneth H.

Peel, Roy $\mathbf{v}$.

Plant, Irving M.

Price, Daniel 0.

Pritzer, Leon
Proschan, Frank
Purcell, Warree

Quirk, Bev. Charles B. 75

$\begin{array}{ll}\text { Raley, P. H. } & 60 \\ \text { Randolph, Lila Knudsen } & 74 \\ \text { Ransmeier, Joseph S. } & \mathbf{3 0}\end{array}$

Rapoport, A. $\quad 68$

Rashevsky, $\mathrm{B}$.

Reagan, Barbara $\mathbf{B}$.

Reder, Melvin W.

Reed, Robert B.

Reerson, Roy L.

Repplier, Theodore $S$.

( 7

Riley, Donald C. $\quad 20,55$

Riordan, John

Robbins, Herbert

Robins, Morton 67

Robison, Sophia M. $\quad$ 42,59

Robson, Douglas $\mathrm{S}$.

Rogers, Thomas W.

Roos, Charles $\mathrm{F}$.

Rosa, Robert V. 


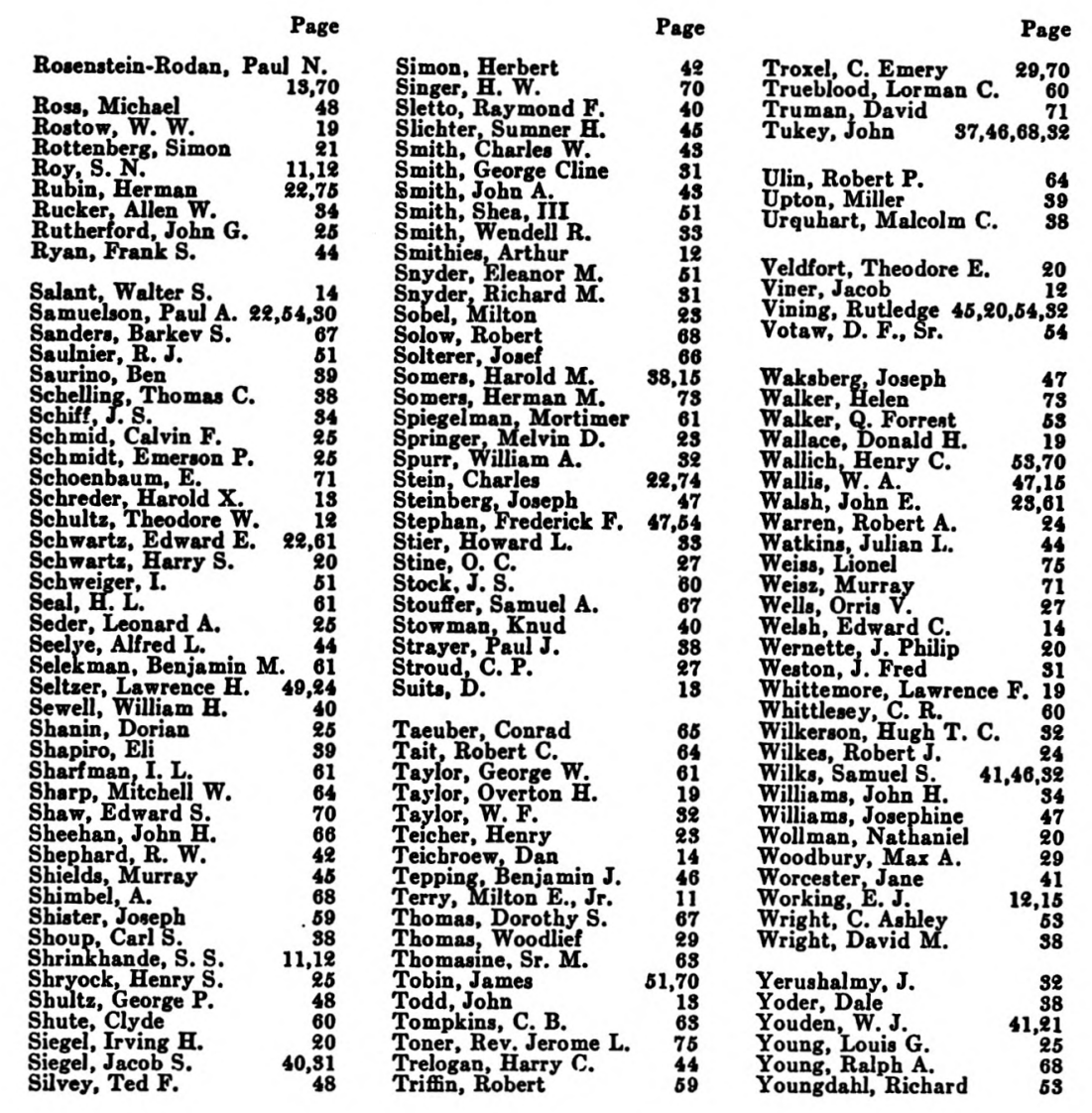

-

\section{ADVERTISERS IN THE PROGRAM}

American Book Company, p. 52

Thomas Y. Crowell, p. 15

Harper and Brothers, p. 26

Richard D. Irwin, Inc., pp. 18, 50

Augustus M. Kelley Company, p. 28

Alfred A. Knopf, p. 16

The Macmillan Company, p. 8

McGraw-Hill Book Company, Pp. $76-77$
National Bureau of Economic Research, Inc., p. 10

W. W. Norton \& Company, Inc., p. 56

Oxford University Press, p. 36

Rinehart \& Company, Inc., p. 62

The Ronald Press Company, pp. 72, 82

John Wiley \& Sons, p. 58

\section{EXHIBITORS AT THE STATLER HOTEL}

\section{(Foyer of the Ballroom)}

American Association of University Presses

American Book Company

The Blakiston Company

Thomas Y. Crowell Company

Harper and Brothers

Henry Holt \& Company, Inc. Houghton Mifflin Company

Institute of Life Insurance

Richard D. Irwin, Inc.

Augustus M. Kelley Company

J. B. Lippincott Company
The Macmillan Company McGraw-Hill Book Company

National Bureau of Economic Research, Inc.

W. W. Norton \& Company, Inc. Oxford University Press

Prentice-Hall, Inc.

Rinehart \& Company, Inc.

The Ronald Press Company South-Western Publishing Com. pany John Wiley and Sons

\section{EXHIBITORS AT THE KENMORE HOTEL}

\section{(Lower Lobby and Wedgewood Room)}

L. G. Balfour Company Frieden Calculating Machine Company

Richard D. Irwin, Inc.

McGraw-Hill Book Company
Prentice-Hall, Inc.

The Ronald Press Company

U. S. Department of Commerce, Bureau of the Census' 


\section{Important Marketing Books}

- ADVERTISING

$B y$ ALBERT WESLEY FREY, Dartmouth College. 746 pages.

- PROFITABLE RETAIL ADVERTISING

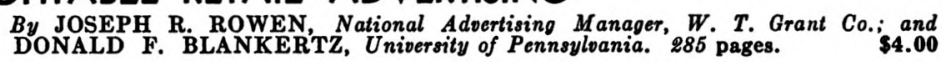

- The ECONOMICS OF INSTALMENT BUYING

By REAVIS COX, University of Pennoylvania, Retail Credit Institute of $A$ merica.
5.56 .0 .0

- MARKETING HANDBOOK

Edited by PAUL H. NYSTROM, Columbia University; and ALBERT WESLEY

- PRINCIPLES of MARKETING

By HAROLD H. MAYNARD and THEODORE N. BECKMAN, both of The Ohio

- PUBLIC RELATIONS

$B y$ WILLLAM A. NIELANDER, Hofstra College; and RAYMOND W. MILLER,
Haraard University. 398 papes.

- MARKETING and DISTRIBUTION RESEARCH

By LYNDON O. BROWN, Daneer-Fitzgerald-Sample, Columbia University. REV ISED

- MARKETING RESEARCH PRACTICE

Edited by DONALD M. HOBART, The Curtis Publishing Co., Past President, The
Am.0rican

- SAlES PROMOTION

$B y$ ALFRED GROSS, and DALE HOUGHTON, both of New York University
45.00

- SALES MANAGEMENT

$B y$ HAROLD H. MAYNARD, The Ohio State University; and HERMAN C. NOLEN,
M6.00

- STANDARDS and LABELS for CONSUMER GOODS

By JESSIE V. COLES, University of California. 566 pages.

- WHOLESALING-Principles and Practice

$B y$ THEODORE N. BECKMAN, The ohio State University; and NATHAN H.
ENGLE, University of Washington. REVISEDEDITION. 746 pages.
$\$ 6.00$

THE RONALD PRESS COMPANY

15 East 26th Street, New York 10 


\section{JOINT COMMITTEE ON LOCAL ARRANGEMENTS}

American Economic Association: Alfred C. Neal, Federal Reserve Bank of Boston American Statistical Association: Wendell D. Macdonald, Bureau of Labor Statistics A merican Marketing Association: Edward C. Bursk, Harvard Businesy School

Amorican Finance Association: Douglas HI. Bellemore, Boston University

Econometric Society: Mrs. Elizabeth Gilhoy, Harvard Un
Institute of

Industrial Relations Research Association: Charles A. Myers. Massachusetts Institute of Technology

American Association of
University Teachers of Insurance: Warner C. Danforth, Boston University

, Boston College

Treasurer: Benjamin F. Stacey, First National Bank of Boston

Publicity: Robertson Page, Federal Reserve Bank of Boston

Employment Register: John H. Bragg, Federal Reserve Bank of Boston

Program Subcommittee

Chairman: George H. Ellis, Federal Reserve Bank of Boston

Members: Dorothy E. Bryant, Federal Reserve Bank of Bosto

Eugene Burlingame, Babson's Reports
E. Gerald Gray, H. B. Humphrey-Alley A. Richards

Fimer Mode, Boston University

Richard Smith, Dewick \& Flanders, Inc.

Robert Solow. Massachusetts Institute of Technolog

Weldon Welfing, Simmons College

\section{Registration Subcommittee}

Chairman: Donald Gilmore; Federal Reserve Bank of Boston

MIembers: Robert Dallas, Boston University
J. K. Horner, Babson Institute
Walter Irard, Harvard University
James McPherson, Boston College
James McPherson, Boston College
Charles A. Myers, Massachusetts Institute of Technology
Jeremiah X. Sullivan, Bureau of Labor Statistics
Jeremiah X. Sullivan, Bureau of Labor Statid
David V. Tiedeman, Harvard University

Information and Recreation Subcommittee

Chairman: Robert Hurley, Liberty Mutual Insurance Company

Members: Reginald

Carroll Ford, Babson Institute

Philip Garrity, Boston College
Robert H. Hogkins, John Hancock Mutual Life Insurance Company

Robert H. Hookins, John Hancock
Carl Kaysen, Harvard University

William D. Mann, U. S. Dept. of Commerce

Donald White, Wage Stabilization Board

PROGRAM ARRANGEMENTS CHAIRMEN

AEA: John H. Williams, Federal Reserve Bank of New York

AMA: Allen W. Rucker, The Eddy-Rucker-Nickels Company

AFA: R.J. Saulnier, Barnard College

IMS: Wassily Leontief, Harvard University

IMS: Joseph F. Daly, Bureau of the Census
IRRA: Frederick H. Harbison, University of Chicago

CEA: Rev. James J. MeGinley, S. J., Fordham University 


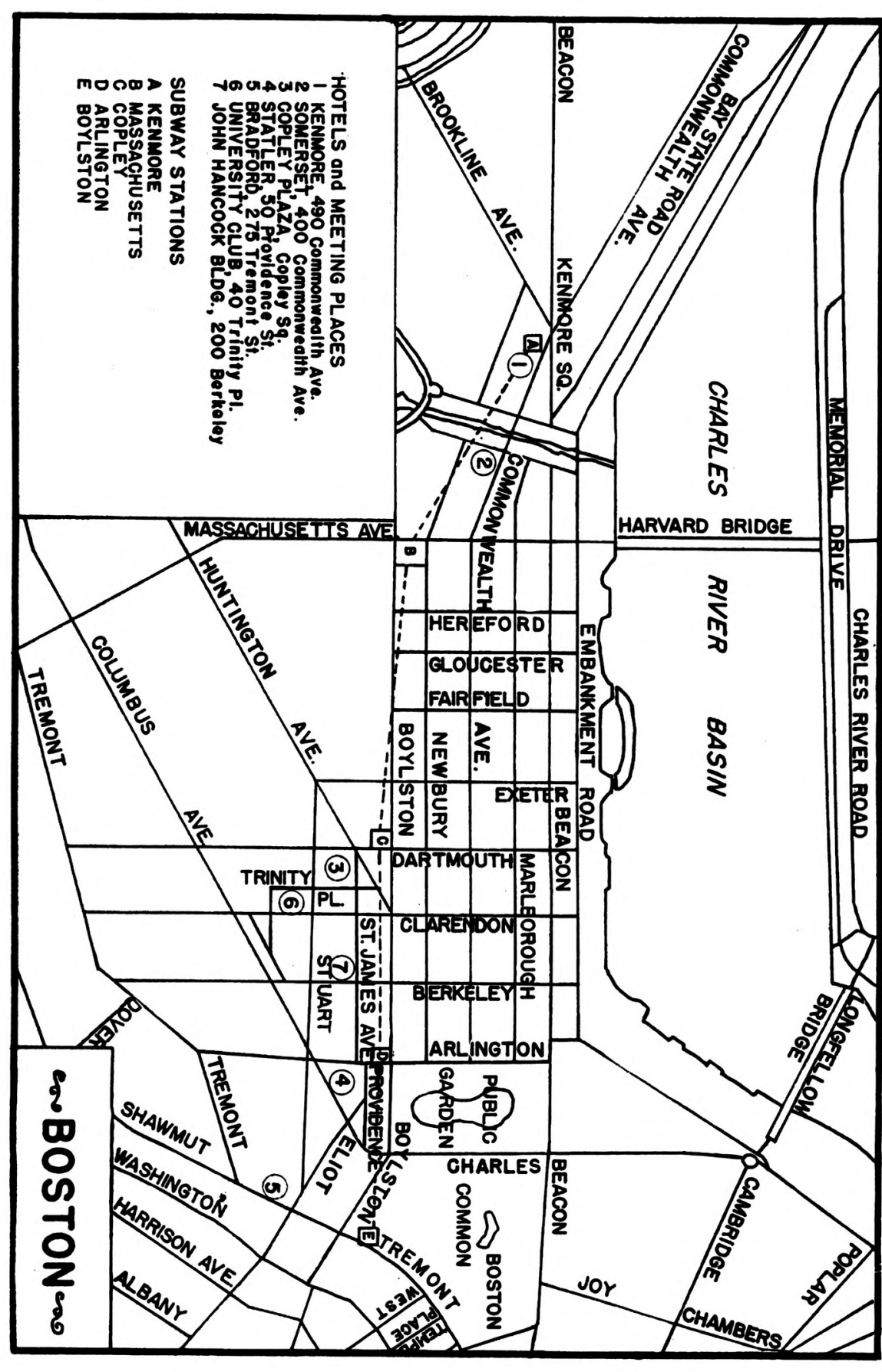


